\title{
Impaired Spatial Memory in Mice Lacking CD3 $\zeta$ Is Associated with Altered NMDA and AMPA Receptors Signaling Independent of T-Cell Deficiency
}

\author{
Antoine Louveau, ${ }^{1}$ Julie Angibaud, ${ }^{1}$ Fabienne Haspot, ${ }^{1}$ Maria Cecilia Opazo, ${ }^{2}$ Reynald Thinard, ${ }^{1}$ Virginie Thepenier, ${ }^{1}$ \\ Stéphane J. Baudouin, ${ }^{1}$ Laurent Lescaudron, ${ }^{1,3}$ Philippe Hulin, ${ }^{4}$ Claudia A. Riedel, ${ }^{2}$ and Hélène Boudin ${ }^{1,5}$ \\ ${ }^{1}$ INSERM Unité Mixte de Recherche 1064, Institut Transplantation Urologie Nephrologie, Centre Hospitalier Universitaire Nantes, Université de Nantes, \\ 44300 Nantes, France; ${ }^{2}$ Facultad de Ciencias Biológicas y Medicina Universidad Andrés Bello, Santiago 8370146, Chile; ${ }^{3}$ Unité de Formation et de Recherche \\ Sciences et Techniques, Université de Nantes, 44300 Nantes, France; ${ }^{4}$ Cellular and Tissular Imaging Core Facility, Université de Nantes (MicroPICell) \\ IFR26, 44300 Nantes, France; and 5INSERM Unité Mixte de Recherche 913, L'Institut des Maladies de l’Appareil Digestif, Université de Nantes, 44035
} Nantes, France

The immunoreceptor-associated protein $\mathrm{CD} 3 \zeta$ is known for its role in immunity and has also been implicated in neuronal development and synaptic plasticity. However, the mechanism by which $\mathrm{CD} 3 \zeta$ regulates synaptic transmission remains unclear. In this study, we showed that mice lacking $\mathrm{CD} 3 \zeta$ exhibited defects in spatial learning and memory as examined by the Barnes maze and object location memory tasks. Given that peripheral T cells have been shown to support cognitive functions and neural plasticity, we generated CD3 $\zeta^{-I-}$ mice in which the peripheral T cells were repopulated to a normal level by syngeneic bone marrow transplantation. Using this approach, we showed that T-cell replenishment in $\mathrm{CD} 3 \zeta^{-1-}$ mice did not restore spatial memory defects, suggesting that the cognitive deficits in CD3 $\zeta^{-1-}$ mice were most likely mediated through a T-cell-independent mechanism. In support of this idea, we showed that CD3 $\zeta$ proteins were localized to glutamatergic postsynaptic sites, where they interacted with the NMDAR subunit GluN2A. Loss of CD3 $\zeta$ in brain decreased GluN2A-PSD95 association and GluN2A synaptic localization. This effect was accompanied by a reduced interaction of GluN2A with the key NMDAR downstream signaling protein calcium/calmodulin-dependent protein kinase II (CaMKII). Using the glycine-induced, NMDA-dependent form of chemical long-term potentiation (LTP) in cultured cortical neurons, we showed that CD3 $\zeta$ was required for activity-dependent CaMKII autophosphorylation and for the synaptic recruitment of the AMPAR subunit GluA1. Together, these results support the model that the procognitive function of CD3 $\zeta$ may be mediated through its involvement in the NMDAR downstream signaling pathway leading to CaMKII-dependent LTP induction.

\section{Introduction}

Many canonical immune molecules are expressed in the nervous system and play important roles in neurodevelopment and synaptic plasticity (Boulanger, 2009). These include molecules of the adaptive immune system, such as members of the major histocompatibility complex class I (MHCI) and of the immunoreceptor-associated CD3 complex (Huh et al., 2000;

\footnotetext{
Received July 17, 2013; revised 0ct. 10, 2013; accepted 0ct. 23, 2013.

Author contributions: A.L., J.A., F.H., L.L., C.A.R., and H.B. designed research; A.L., J.A., F.H., M.C.O., R.T., V.T., S.J.B., and P.H. performed research; A.L., J.A., F.H., and H.B. analyzed data; A.L. and H.B. wrote the paper.

This work was supported by INSERM, Fondation Progreffe, and ECOS-CONICYT (Grant C11S03). We thank Dr. I. Anegon, Dr. D. Laplaud, and Dr. P. Naveilhan for support and the European Mouse Mutant Archive for $\mathrm{CD} 3 \zeta^{-1-}$ mice.

The authors declare no competing financial interests.

Correspondence should be addressed to Helene Boudin, INSERM Unité Mixte de Recherche 913, University of Nantes, 1, rue Gaston Veil, 44035 Nantes, France. E-mail: helene.boudin@univ-nantes.fr.

J. Angibaud's present address: Interdisciplinary Institute for Neuroscience, CNRS Unité Mixte de Recherche 5297, Université Bordeaux Segalen, 33077 Bordeaux cedex, France.

S.J. Baudouin's present address: Biozentrum Universität Basel, Basel CH-4056, Switzerland.

L. Lescaudron's present address: Unité Mixte de Recherche 791, LIOAD, UFR d'Odontologie, University of Nantes, 44035 Nantes, France.

DOI:10.1523/JNEUROSCI.3028-13.2013

Copyright $\odot 2013$ the authors $\quad 0270-6474 / 13 / 3318672-14 \$ 15.00 / 0$
}

Goddard et al., 2007; Nakamura et al., 2007; Baudouin et al.,

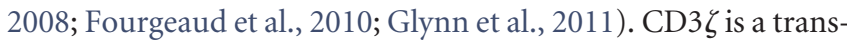
membrane adaptor signaling protein first characterized in $\mathrm{T}$ cells as a component of the CD3 complex, the signaling module of the TCR. This receptor recognizes peptide fragments presented by $\mathrm{MHC}$ molecules and is thus responsible for antigenic recognition (Samelson et al., 1985). Moreover, CD3 $\zeta$ participates in intrathymic T-cell differentiation, which is arrested in mice lacking $\mathrm{CD} 3 \zeta$, leading to a marked reduction of circulating T cells (Liu et al., 1993; Love et al., 1993; Malissen et al., 1993). Genetic inactivation of $\mathrm{CD} 3 \zeta$ also highlighted its critical role in neuronal development and plasticity. At early developmental stages, CD3 $\zeta$ acts as a downstream mediator of the ephrinA1/EphA4 signaling pathway to inhibit neurite extension (Angibaud et al., 2011) and is required for activity-dependent refinement of the retinal ganglion cell axon projections to the thalamus (Huh et al., 2000; Xu et al., 2010). In addition, CD3 $\zeta$ negatively regulates dendritic complexity in retinal ganglion cells and cultured hippocampal neurons (Baudouin et al., 2008; Xu et al., 2010). Synaptic functions were also altered in $\mathrm{CD} 3 \zeta$-deficient mice, which showed a reduced glutamatergic synaptic activity in the retina ( $\mathrm{Xu}$ et al., 
2010) and defects in synaptic plasticity in the hippocampus, as reflected by an enhanced long-term potentiation (LTP) and a lack of long-term depression (Huh et al., 2000; Barco et al., 2005). However, the role of $\mathrm{CD} 3 \zeta$ in synaptic-plasticity-dependent cognitive behavior, in particular in learning and memory, is currently unknown. In addition, the mechanisms by which CD3 $\zeta$ regulates synaptic function remain poorly understood and might be initiated by two distinct but nonexclusive processes. One process would involve immune-mediated mechanisms triggered by peripheral $\mathrm{CD} 3 \zeta$-expressing $\mathrm{T}$ cells. Indeed, several studies indicated that circulating $\mathrm{T}$ cells play a supportive role in cellular plasticity important in neurogenesis and cognition (Brynskikh et al., 2008; Wolf et al., 2009; Derecki et al., 2010; Kipnis et al., 2012), suggesting that the decreased level of circulating T cells in $\mathrm{CD} 3 \zeta$ deficient mice might affect neural plasticity. The second process would rely on a direct regulation of glutamate receptors distribution and downstream signaling pathways by neuronal $\mathrm{CD} 3 \zeta$ known to localize at glutamatergic synapses (Baudouin et al., 2008).

In this study, we examined the role of $\mathrm{CD} 3 \zeta$ in spatial learning and working memory. In addition, we explored the significance of the aforementioned mechanisms in $\mathrm{CD} 3 \zeta$-mediated cognitive behavior and neuronal plasticity. Our data showed that CD3 $\zeta$ deficient mice exhibited impaired learning and memory that was independent of T-cell deficiency but associated with decreased synaptic GluN2A and altered NMDA-dependent plasticity manifest by inhibition of calcium/calmodulin-dependent protein kinase II (CaMKII) activation and GluA1 synaptic recruitment.

\section{Materials and Methods}

\section{Animals}

$\mathrm{C} 57 \mathrm{BL} / 6 \mathrm{CD} 45.2^{+} \mathrm{CD} 3 \zeta^{+/-}$mice were obtained from the CDTA center in Orleans (France). Animals were maintained as heterozygotes on a C57BL/6 background. Newborns or 17-d-old mice embryos were genotyped by PCR amplification as described previously (Malissen et al., 1993). C57BL/6 CD $45.1^{+}$mice were obtained from Charles River Laboratories. Mice were maintained on a $12 \mathrm{~h}$ light-dark cycle in a temperature-controlled room with ad libitum access to water and food. Age-matched littermates were used for all experiments. All protocols were performed in accordance with French standard ethical guidelines for laboratory animals (Agreements \#CEEA.2012.42, CEEA.2012.43, CEEA.2012.44).

\section{RNA extraction and PCR}

Total RNAs were extracted from 8-week-old $\mathrm{CD} 3 \zeta^{+/+}$and $\mathrm{CD} 3 \zeta^{-/-}$ mice hippocampi and homogenized in $1 \mathrm{ml}$ of TRIzol reagent for $5 \mathrm{~min}$ at room temperature, followed by chloroform extraction and isopropanol precipitation. After centrifugation and washing in ethanol, RNA was resuspended in water. After Turbo DNase treatment (Invitrogen), $2 \mu \mathrm{g}$ of RNA was reverse transcribed with a MMLV-reverse transcriptase system (Invitrogen). The synthesized cDNA (200 ng) was denatured for 10 min at $96^{\circ} \mathrm{C}$ and subjected to 40 cycles of $3 \mathrm{~s}$ at $96^{\circ} \mathrm{C}, 3 \mathrm{~s}$ at $60^{\circ} \mathrm{C}, 50 \mathrm{~s}$ at $68^{\circ} \mathrm{C}$, and a final extension step of $10 \mathrm{~s}$ at $72^{\circ} \mathrm{C}$ using the Veriti Thermal cycler (Applied Biosystems). The reaction occurred in a total volume of $20 \mu \mathrm{l}$ using the AmpliTaq Gold PCR Master Mix (Applied Biosystems). For the amplification of $\mathrm{CD} 3 \zeta \mathrm{mRNA}$, the sense oligonucleotide primer was 5' -AGGGAAGCAGAAGATGAAGTGG-3' and the antisense oligonucleotide primer was $5^{\prime}$-TATGCAGGGCATCATAGGTGTC-3' giving rise to a 485 and $380 \mathrm{bp}$ fragment mRNA for $\mathrm{CD} 3 \zeta^{+/+}$and $\mathrm{CD} 3 \zeta^{-/-}$ mice, respectively. Internal standards were generated by amplifying the GAPDH mRNA using the following oligonucleotide primers: $5^{\prime}$-CTAC AGCAACAGGGTGGTGG-3' (sense) and 5' -TATGGGGGTCTGGGAT GG-3' (antisense). PCR products were loaded on a $1 \%$ agarose gel for analysis.

\section{Behavioral studies}

Barnes maze task. The Barnes maze task was used to assess spatial reference memory (Barnes, 1979). One of the advantages of the Barnes maze task is that it is not influenced by stress as much as other similar tasks and no strong aversive stimuli or deprivation are used as reinforcement. The apparatus used in this experiment consisted of a white circular platform ( $90 \mathrm{~cm}$ in diameter) elevated $1 \mathrm{~m}$ above the floor, with 20 equally spaced holes ( $5 \mathrm{~cm}$ diameter) at the periphery of the maze. A dark escape box was placed under only one hole randomly chosen for each mouse. The maze was placed in a room with distal environmental cues to allow mice to properly locate the target hole. An aversive noise (Combo Tuner Metronome TM40; Korg) was used as motivation to escape in the dark box. The apparatus was clean between each trial to prevent the use of local olfactory cues. The test was divided in two phases. Mice were trained 4 times/d for $4 \mathrm{~d}$ to find the target hole. Sessions within each day were separated by $15 \mathrm{~min}$. Memory performance of the mice was assessed by one trial performed $24 \mathrm{~h}$ (day 5 [D5]) and $8 \mathrm{~d}$ (D12) after the last training. A video camera was used to record the behavior of the mice during both the training sessions and the tests. For the training sessions, mice were gently picked up from the tail and placed for $10 \mathrm{~s}$ in the middle of the platform under a box before the beginning of the session. After $3 \mathrm{~min}$, if the mice did not find the correct hole, they were gently directed toward the target hole and allowed to descend into the escape box, where they were left for $1 \mathrm{~min}$ in an aversive noise-free environment. The time to enter into the target hole and the velocity of the mice were measured. Search strategies used by the mice to locate the target hole during the training were analyzed. Search strategies were scored as random if the mouse displayed a nonsystematic search strategy with multiple crossings through the center of the maze or if it did not locate the hole within the $3 \mathrm{~min}$. Search strategies were scored as serial if the mouse moved around the edge of the maze and past at least three adjacent holes before entering the escape hole. Finally, search strategies were scored as spatial if the mouse moved directly toward the direction of the escape hole from the center of the maze, and did not explore a hole more than two holes away from the target hole. Proportion of random, serial, and spatial strategies was scored for each days of training and compared between mouse genotypes. For the tests trials (D5 and D12), the escape box was removed and mice were allowed to explore the maze for $90 \mathrm{~s}$. The number of visits (when a mouse dipped its head into a hole) into the target hole and the two direct adjacent holes were measured. $\mathrm{CD} 3 \zeta^{+/+}, \mathrm{CD} 3 \zeta^{+/-}$, and $\mathrm{CD} 3 \zeta^{-1-}$ naive and grafted ( $42 \mathrm{~d}$ after graft) mice at 12 weeks of age were used for this study. Analyses were performed on 8-11 animals per group. Data are presented as mean \pm SEM. Data analysis was performed using Excel and GraphPad Prism 5 software and statistical analyses were performed using two-way ANOVA with Bonferroni post hoc test.

Object location memory task. The experimental apparatus used in this study was a square box made of opaque white plastic $(50 \mathrm{~cm} \times 50 \mathrm{~cm})$. The mice were first habituated to the box for $15 \mathrm{~min}$ and were then placed for $10 \mathrm{~min}$ in the box with four different plastic objects positioned in a defined spatial orientation (training). Twenty-four hours later, the mice were placed in the same box with the same four objects, but two of them had switched locations (test). The time spent exploring the objects in novel and old (familiar) locations was measured for $10 \mathrm{~min}$. Exploration of an object was assumed when the mouse approached an object and touched it with its vibrissae, snout, or forepaws. The object location preference was calculated as the exploration time of the old or novel location objects/total exploration time. Analyses were performed on 12week-old CD3 $\zeta^{+/+}(n=6), \mathrm{CD}^{3} \zeta^{+/-}(n=4)$, and $\mathrm{CD} 3 \zeta^{-1-}(n=5)$ mice. Data analyses were performed using Excel and GraphPad Prism 5 software and statistical analyses were performed using two-way ANOVA with Bonferroni post hoc test.

\section{Bone marrow transplantation}

Age-matched $\mathrm{CD} 45.2^{+}$(6 weeks old) $\mathrm{CD} 3 \zeta^{+/+}$and $\mathrm{CD} 3 \zeta^{-1-}$ mice (recipient mice) were anesthetized with an intramuscular injection of Rompun/Ketalar (4 mg/kg xylazine; $40 \mathrm{mg} / \mathrm{kg}$ ketamine) and received $\mathrm{x}$-ray total body irradiation (2 Gy; Faxitron $160 \mathrm{CP}$ ) 6-10 h before bone marrow transplantation (BMT). BM cells (BMCs) were isolated from adult CD $45.1^{+} \mathrm{C} 57 \mathrm{BL} / 6$ female mice (donor mice) by flushing the tibiae 
and femurs using a 26-gauge needle with Media 199 containing $10 \mathrm{~mm}$ HEPES (Invitrogen), $10 \mu \mathrm{g} / \mathrm{ml}$ DNase (Sigma Aldrich), and $4 \mu \mathrm{g} / \mathrm{ml}$ gentamycin (BioWhittaker). After filtration through a $100 \mu \mathrm{m}$ filter, BMCs were centrifuged for $5 \mathrm{~min}$ at $800 \times g$ at $4^{\circ} \mathrm{C}$. BMCs were resuspended in Media 199 containing $10 \mathrm{~mm}$ HEPES (Invitrogen), $10 \mu \mathrm{g} / \mathrm{ml}$ DNase (Sigma Aldrich), and $4 \mu \mathrm{g} / \mathrm{ml}$ gentamycin (BioWhittaker) at a density of $30.10^{6}$ cells $/ \mathrm{ml}$. Recipient mice were injected intravenously with $15 \times 10^{6}$ cells.

\section{Flow cytometry analysis}

Two, 6, and 8 weeks after BMT, grafted $\mathrm{CD} 3 \zeta^{+/+}(n=11)$ and grafted $\mathrm{CD} 3 \zeta^{-1-}(n=10)$ mice were anesthetized with $4 \%$ isoflurane (Forene) with $0.8 \mathrm{~L} / \mathrm{min}$ of $\mathrm{O}_{2}$ and $300 \mu$ l of blood was collected from the maxillary vein with a 20 -gauge needle in an Eppendorf with $20 \mu \mathrm{l}$ of heparin. The same procedure was performed with 12 -week-old naive $\mathrm{CD}^{3} \zeta^{+/+}(n=$ $7)$ and $\operatorname{CD} 3 \zeta^{-1-}(n=9)$ mice. After red cell lysis, peripheral blood cells were suspended in FACS buffer ( $10 \mathrm{~g} / \mathrm{L} \mathrm{BSA}$ and $0.1 \%$ azide in PBS) and stained for $30 \mathrm{~min}$ for extracellular markers with antibodies for CD45.2 conjugated to fluorescein isothiocyanate (FITC, $1 \mu \mathrm{g} / \mathrm{ml}$; BD Biosciences), and CD $3 \varepsilon$ ( $2 \mu \mathrm{g} / \mathrm{ml}$; BD Biosciences) or TCR $\beta(1 \mu \mathrm{g} / \mathrm{ml}$; BD Biosciences) conjugated with phycoerythrin. Labeled cells were analyzed with a FACS LSR II (BD Biosciences) and FlowJo software (TreeStar). To obtain an accurate cell count, cells were gated using forward versus side scatter to eliminate debris, pulse width versus area to select singlet cells, and DAPI labeling to eliminate dead cells. Data analyses were performed using Excel and GraphPad Prism 5 and statistical analyses were performed using a Kruskal-Wallis test with Dunn post hoc test.

\section{Culture of cortical neuron and pharmacological treatments}

Cultures of astrocytes were first prepared to constitute a glial feeder layer. Briefly, the cortex was dissected from postnatal day 1 newborn rat forebrains and dissociated by trypsin and DNase. Cells were then plated at a density of $35 \times 10^{3}$ cells $/ \mathrm{cm}^{2}$ in minimal essential medium (MEM) containing $10 \%$ FCS, $0.6 \%$ D-glucose, and $100 \mu \mathrm{g} / \mathrm{ml}$ streptomycin. The medium was replaced with serum-free MEM containing N2.1 supplements $24 \mathrm{~h}$ before the neuron culture.

Mouse cortical neuron culture was prepared from embryonic day 17 brains of CD $3 \zeta^{-1-}$ and $\mathrm{CD} 3 \zeta^{+/+}$littermate mice and genotyped by PCR amplification as described above. After dissection of the cortex, the tissue was enzymatically dissociated with trypsin and mechanical trituration. Cells were plated on glass coverslips coated with poly-L-lysine $(1 \mathrm{mg} / \mathrm{ml}$; Sigma Aldrich) at a density of $7 \times 10^{3}$ cells $/ \mathrm{cm}^{2}$ for immunostaining or $18 \times 10^{3}$ cells $/ \mathrm{cm}^{2}$ for Western blot in neuronal plating medium composed of MEM containing 10\% FCS, $0.6 \%$ D-glucose, $100 \mu \mathrm{g} / \mathrm{ml}$ streptomycin, $100 \mathrm{UI} / \mathrm{ml}$ penicillin, and $1 \mathrm{~mm}$ sodium pyruvate. Cells were transferred $3 \mathrm{~h}$ later to a dish containing a glial feeder layer in serum-free MEM containing N2.1 supplements. At $2 \mathrm{~d}$ in vitro (DIV), $5 \mu \mathrm{M}$ cytosine arabinoside was added. Cells were used at 15 DIV for both immunostaining and Western blot.

For glycine-induced long-term potentiation (Gly-LTP), 15 DIV neurons were incubated for $5 \mathrm{~min}$ in a $\mathrm{Mg}^{2+}$-free ACSF containing the following (in mM): $125 \mathrm{NaCl}, 2.5 \mathrm{KCl}, 26.2 \mathrm{NaHCO}_{3}, 1 \mathrm{NaH}_{2} \mathrm{PO}_{4}, 11$ glucose, and $2.5 \mathrm{CaCl}_{2}$ with $100 \mu \mathrm{M}$ glycine (Sigma Aldrich), followed by a 15 min incubation in ACSF supplemented with $1.25 \mathrm{mM} \mathrm{MgCl}_{2}$. For forskolin/rolipram treatment (F/R), 15DIV neurons were incubated for $16 \mathrm{~h}$ with $50 \mu \mathrm{M}$ forskolin (Sigma Aldrich) and $0.1 \mu \mathrm{M}$ rolipram (Sigma Aldrich) in neuronal culture medium. After treatment, cells were fixed for immunostaining or collected for Western blot analyses.

\section{Immunostaining}

Neurons at 15 DIV were fixed in PBS containing 4\% paraformaldehyde (PFA) and 4\% sucrose for 15 min except for NMDA receptor immunostaining, for which cells were fixed in $\mathrm{MeOH}$ for $20 \mathrm{~min}$ at $-20^{\circ} \mathrm{C}$. Neurons were permeabilized for $5 \mathrm{~min}$ at room temperature (RT) in $0.25 \%$ Triton X-100 in PBS (only if PFA fixation), washed twice with $\mathrm{PBS}$, and incubated for $30 \mathrm{~min}$ at $37^{\circ} \mathrm{C}$ in PBS containing $10 \%$ BSA. Neurons were incubated overnight at RT with primary antibodies diluted in PBS containing 3\% BSA and $0.02 \%$ azide. Antibodies used were the following: rabbit anti-CD3 $\zeta$ ( $1 \mu \mathrm{g} / \mathrm{ml}$; Spring Bioscience), mouse anti-PSD95 ( $1 \mu \mathrm{g} / \mathrm{ml}$; Abcam), mouse anti-glutamic acid decarbox- ylase (anti-GAD, 1:2; Hybridoma Bank), rabbit anti-GluA1 $(0.5 \mu \mathrm{g} / \mathrm{ml}$; Calbiochem), mouse anti-GluN1 (2.5 $\mu \mathrm{g} / \mathrm{ml}$; BD Pharmingen), rabbit anti-GluN2A ( $5 \mu \mathrm{g} / \mathrm{ml}$; Millipore), mouse anti-GluN2B ( $5 \mu \mathrm{g} / \mathrm{ml}$; NeuroMab), mouse anti-CaMKII $\alpha$ (5.8 $\mu \mathrm{g} / \mathrm{ml}$; Affinity Bioreagents), mouse anti-SV2 (Hybridoma Bank); mouse anti-Synapsin I ( $2 \mu \mathrm{g} / \mathrm{ml}$; Synaptic Systems), and rabbit anti-Synapsin I ( $0.02 \mu \mathrm{g} / \mathrm{ml}$; Sigma). After washing, neurons were incubated for $45 \mathrm{~min}$ at $37^{\circ} \mathrm{C}$ with the appropriate FITCconjugated or Alexa Fluor 568-conjugated secondary antibodies diluted in PBS containing 3\% BSA and $0.02 \%$ azide. Neurons were washed with PBS and mounted with ProLong Gold Antifade Reagents with DAPI (Invitrogen).

\section{Image analyses and quantification}

Images were acquired with $63 \times$, numerical aperture (NA) 1.4 oilimmersion objective using a digital camera (AxioCam HRC; Zeiss) driven by AxioVision Release 4.2 software. For 3D reconstruction, highresolution confocal image stacks were acquired using a Leica SP1 laser scanning microscope equipped with argon $488 \mathrm{~nm}$, DPSS $561 \mathrm{~nm}$, and He-Ne $594 \mathrm{~nm}$ lasers and a $63 \times$, NA 1.4 oil-immersion objective. In each sample, the two fluorophores (Alexa Fluor 488 paired with Alexa Fluor 594) were imaged separately using sequential scanning to eliminate the possibility of overlapping emission. The step size of the $z$-stack was 0.25 $\mu \mathrm{m}$. The 3D reconstruction was performed using Amira 3D V4.1 Software (Visualization Sciences Group).

The quantification was performed using ImageJ software. The number of clusters (GluN1, GluN2A, GluN2B, GluA1, and PSD95) per length unit of dendrite was determined for each selected neuron in one to two dendrites. To define clusters, thresholds for individual neurons and channels was chosen manually and corresponded to at least two times the average intensity of fluorescence in the dendritic shaft. To define synaptic clusters, the binary images of each postsynaptic molecule (GluN1, GluN2A, GluN2B, GluA1, and PSD95) were compared with binary images of synapsin clusters. Any postsynaptic cluster that had at least one pixel of overlap with a presynaptic cluster was defined as synaptic. For Gly-LTP experiments, the percentage of synaptic GluA1 clusters corresponds to the percentage of thresholded GluA1 puncta overlapping with a binary image of the PSD95 image. The number of CaMKIIimmunoreactive spines was counted in two dendrites of each selected neurons.

A total of 30-40 neurons were analyzed for each experimental condition from three to four independent cultures. Data analysis was performed using GraphPad Prism 5.0 software. Values indicate mean \pm SEM. Group comparison was made by Student's $t$ test or by two-way ANOVA with Bonferroni post hoc test as indicated.

\section{Western blot and co-immunoprecipitation}

To analyze $\mathrm{CD} 3 \zeta$ protein expression, forebrains from adult $\mathrm{CD} 3 \zeta^{+/+}$ $(n=5)$ and $\operatorname{CD} 3 \zeta^{-1-}(n=6)$ mice were homogenized using a Teflon homogenizer in RIPA lysis buffer (50 mm Tris, $150 \mathrm{~mm} \mathrm{NaCl}, 1 \%$ NP40, $0.5 \%$ sodium deoxycholate, $0.1 \%$ SDS, 1 mm EDTA, pH 8.0 ) and solubilized for $30 \mathrm{~min}$ at $4^{\circ} \mathrm{C}$. The resulting suspension was centrifuged at $20,000 \times g$ for $20 \mathrm{~min}$ and the supernatant was analyzed by Western blot. The synaptosome and synaptic membrane fractions were obtained from forebrains of 30-d-old Sprague Dawley rats. Forebrains were homogenized using a Teflon homogenizer in $5 \mathrm{~mm}$ Tris- $\mathrm{HCl}$, pH 7.4, containing $320 \mathrm{~mm}$ sucrose, $0.5 \mathrm{~mm}$ EGTA, and protein inhibitor mixture (PIC; Sigma Aldrich). After centrifugation at $1000 \times g$ for $10 \mathrm{~min}$, the supernatant (S1) was saved. The pellet was washed, homogenized in the previous buffer, and centrifuged for $10 \mathrm{~min}$ at $1000 \times \mathrm{g}$. The second supernatant (S2) was collected, mixed with the first supernatant (S1), and then centrifuged at $4^{\circ} \mathrm{C}$ for $20 \mathrm{~min}$ at $12,000 \times \mathrm{g}$. The pellet (total membrane fraction P2) was resuspended in $5 \mathrm{~mm}$ Tris- $\mathrm{HCl}, \mathrm{pH} 8.1$, containing $320 \mathrm{~mm}$ sucrose, $0.5 \mathrm{~mm}$ EGTA, and $1 \mathrm{~mm}$ dithiothreitol. The resulting suspension was layered on a discontinuous sucrose step gradient $(0.32 \mathrm{M} / 1 \mathrm{~m} / 1.2 \mathrm{~m}$ sucrose in $5 \mathrm{~mm}$ Tris- $\mathrm{HCl}, \mathrm{pH} 8.1)$ and centrifuged at $150,000 \times g$ for $2 \mathrm{~h}$ at $4^{\circ} \mathrm{C}$. The synaptosome fraction was collected at the interface between the $1 / 1.2 \mathrm{M}$ sucrose gradient and diluted 10 times with the lysis buffer ( 5 mM Tris- $\mathrm{HCl}, \mathrm{pH} 8.1$, containing 0.5 mm EGTA). For synaptic membrane preparation, the synaptosome fraction was in- 
cubated under soft agitation for $30 \mathrm{~min}$ at $4^{\circ} \mathrm{C}$. The lysed solution was centrifuged at $33,000 \times \mathrm{g}$ for $30 \mathrm{~min}$ at $4^{\circ} \mathrm{C}$ and the pellet was resuspended in $5 \mathrm{~mm}$ Tris- $\mathrm{HCl}$, pH 8.1, containing $320 \mathrm{~mm}$ sucrose, $0.5 \mathrm{~mm}$ EGTA, and $1 \mathrm{~mm}$ dithiothreitol. The resulting suspension was layered on a discontinuous sucrose step gradient $(0.32 \mathrm{M} / 1 \mathrm{~m} / 1.2 \mathrm{M}$ sucrose in $5 \mathrm{~mm}$ Tris- $\mathrm{HCl}, \mathrm{pH} 8.1)$ and centrifuged at $250,000 \times g$ for $1 \mathrm{~h}$ at $4^{\circ} \mathrm{C}$. The synaptic membrane fraction was collected at the interface between the $1 / 1.2 \mathrm{~m}$ sucrose gradient.

To analyze the protein expression of the synaptic receptors (GluN1, GluN2A, GluN2B, and GluN1) in $\mathrm{CD} 3 \zeta^{+/+}$and $\mathrm{CD} 3 \zeta^{-/-}$mice brains, membrane brain homogenates (P2) and synaptosome-enriched fractions were generated. Forebrains from adult $\operatorname{CD} 3 \zeta^{+/+}(n=4)$ and CD3 $\zeta^{-1-}(n=4)$ mice were homogenized using a glass Teflon homogenizer in $10 \mathrm{~mm}$ Tris- $\mathrm{HCl}, \mathrm{pH}$ 7.4, containing $320 \mathrm{~mm}$ sucrose and PIC. The resulting suspension was centrifuged at $700 \times \mathrm{g}$ for $10 \mathrm{~min}$. The supernatant was collected, centrifuged at $100,000 \times g$ for $30 \mathrm{~min}$, and the pellet was resuspended in $10 \mathrm{~mm}$ Tris- $\mathrm{HCl}, \mathrm{pH} 7.4$ (P2). For the synaptosome-enriched membrane fraction, the pellet of the membrane fraction was resuspended in $5 \mathrm{~mm}$ Tris- $\mathrm{HCl}, \mathrm{pH} 8.1$, containing $0.5 \%$ of Triton X-100, $320 \mathrm{~mm}$ sucrose, and PIC and solubilized for $1 \mathrm{~h}$ at $4^{\circ} \mathrm{C}$. The resulting suspension was centrifuged at $100,000 \times g$ for $1 \mathrm{~h}$ at $4^{\circ} \mathrm{C}$. The pellet was then resuspended in the same buffer and centrifuged at $100,000 \times g$ for $1 \mathrm{~h}$ at $4^{\circ} \mathrm{C}$. The pellet was resuspended in $5 \mathrm{~mm}$ Tris- $\mathrm{HCl}$, $\mathrm{pH} 8.1$, containing $0.5 \%$ of Triton X-100, $320 \mathrm{~mm}$ sucrose, and PIC.

For neuronal culture analyses, 15 DIV neurons were scrapped into cold PBS containing PIC, pelleted, and resuspended in Laemmli buffer. Analyses were performed on 3-4 different cell cultures.

For co-immunoprecipitation (co-IP), membrane brain homogenates from $\mathrm{CD} 3 \zeta^{+/+}(n=4)$ and $\mathrm{CD} 3 \zeta^{-/-}(n=4)$ brains were solubilized in TBS (50 mu Tris-HCl, $0.15 \mathrm{M} \mathrm{NaCl}, \mathrm{pH} 7.4$ ) containing $1 \%$ Triton X-100 and PIC for $4 \mathrm{~h}$ at $4^{\circ} \mathrm{C}$. After centrifugation for $30 \mathrm{~min}$ at $20,000 \times \mathrm{g}$, the supernatant was collected and incubated overnight with $4 \mu \mathrm{g}$ of rabbit

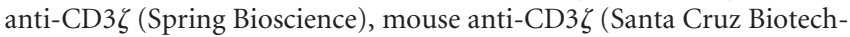
nologies), anti-GluN2A (Millipore), or anti-GluN2B (Millipore) antibodies coupled to protein A or protein G Sepharose beads (GE Healthcare). After centrifugation for $2 \mathrm{~min}$ at $3000 \times g$, the pellet was washed with TBS containing $1 \%$ Triton X-100 and PIC and then twice with Tris- $\mathrm{NaCl}$ (50 mu Tris- $\mathrm{HCl}, 300 \mathrm{~mm} \mathrm{NaCl}, \mathrm{pH}$ 7.4) and twice with TBS. After centrifugation for $2 \mathrm{~min}$ at $3000 \times g$, the beads were resuspended in Laemmli buffer and analyzed by immunoblot. For control experiments, the same procedure was followed except that the solubilized membrane suspension was added to Sepharose beads coupled to control IgG antibodies.

All samples $(7-30 \mu \mathrm{g})$ were boiled at $95^{\circ} \mathrm{C}$ for $5 \mathrm{~min}$ and then transferred to ice before being loaded on a $10 \%$ SDS-PAGE and transferred to a nitrocellulose membrane. The membrane was blocked with $5 \%$ dried milk in 20 mm Tris- $\mathrm{HCl}$, pH 7.4, containing $0.45 \mathrm{M} \mathrm{NaCl}$ and $0.1 \%$ Tween 20 (TBST), except for phosphoprotein, for which the membrane was blocked with $5 \%$ BSA in TBST. The membrane was then incubated overnight with a primary antibody diluted in TBST containing 5\% dried milk (5\% BSA for phosphoprotein). The primary antibodies used in this study were as follows: mouse anti-EphA4 ( $1 \mu \mathrm{g} / \mathrm{ml}$; Invitrogen), rabbit anti-CD3 $\zeta(0.5 \mu \mathrm{g} / \mathrm{ml}$; Spring Bioscience), mouse anti-PSD95 ( $1 \mu \mathrm{g} / \mathrm{ml}$; Abcam), mouse anti-GluN1 $(1 \mu \mathrm{g} /$ $\mathrm{ml}$; BD Pharmingen), rabbit anti-GluN2A ( $2 \mu \mathrm{g} / \mathrm{ml}$; Millipore), mouse antiGluN2B (2 $\mu \mathrm{g} / \mathrm{ml}$; NeuroMab), rabbit anti-GluA1 (5 $\mu \mathrm{g} / \mathrm{ml}$; Calbiochem), rabbit anti-Phospho831 GluA1 (Millipore), rabbit anti-Phospho286 CaMKII (1:200; Promega), mouse anti-CaMKII $\alpha(0.5 \mu \mathrm{g} / \mathrm{ml}$; Thermo Scientific), or mouse anti-GAPDH $(0.2 \mu \mathrm{g} / \mathrm{ml}$; Santa Cruz Biotechnologies). The membrane was then washed in TBST, incubated for $1 \mathrm{~h}$ in peroxidaseconjugated goat anti-rabbit antibody (1:1000) or in peroxidase-conjugated donkey anti-mouse antibody (1:1000), and visualized using an enhanced chemiluminescence kit (GE Healthcare) and Fujifilm LAS-400 imaging analysis system. Quantification of signal intensity was performed using $\mathrm{Mu}-$ ligauge V3.0 software. For phosphorylation analysis, signal intensity of the phosphoprotein was divided by the signal of the total protein and normalized to control values. The statistical analysis was performed using two-way ANOVA with Bonferroni post hoc test. For co-IP quantification, signal intensity of the co-IP protein was normalized to the signal intensity of the protein in the input sample and then divided by the signal intensity of the immunoprecipitated protein. All statistical analyses were performed using GraphPad Prism 5 software.

\section{Results \\ $\mathrm{CD} 3 \zeta$ knock-out leads to spatial learning and working memory deficits}

The expression of a nonfunctional truncated CD3 $\zeta$ mRNA lacking exon 2 was verified in the hippocampi of $\mathrm{CD} 3 \zeta^{-1-}$ mice (Fig. $1 A)$. Immunoblots from mouse brain homogenates labeled with $\mathrm{CD} 3 \zeta$ antibody confirmed that no $\mathrm{CD} 3 \zeta$ protein was expressed in the knock-out mice, as described previously (Fig. $1 B$; Malissen et al., 1993).

Ten- to 12 -week-old CD3 $\zeta^{-1-}$ mice did not differ significantly from congenic $\mathrm{CD} 3 \zeta^{+/+}$animals in overall health and appearance, body weight, or spontaneous behavior in the home cage. The learning and spatial memory performances of $\mathrm{CD} 3 \zeta^{-/-}$mice were evaluated with the Barnes circular maze test, a hippocampus-dependent cognitive task that requires spatial reference memory (Barnes, 1979; Bach et al., 1995). Both $\mathrm{CD} 3 \zeta^{+/+}(n=8)$ and $\mathrm{CD} 3 \zeta^{-/-}(n=11)$ mice learned to locate the escape hole with the hidden box during the course of the training period (D1-4), as indicated by a progressive reduction in the time needed to reach the target hole (Fig. $1 C$ ). However, $\mathrm{CD} 3 \zeta^{-1-}$ mice did not perform as well as $\mathrm{CD} 3 \zeta^{+/+}$mice, as indicated by a significant increase of the time needed to find the escape hole at D2 and D4 of the training compared with $\mathrm{CD} 3 \zeta^{+/+}$mice $\left(\mathrm{D} 2: \mathrm{CD} 3 \zeta^{+/+}: 96.5 \pm 11.3 \mathrm{~s} ; \mathrm{CD} 3 \zeta^{-/-}: 142.8 \pm\right.$ $11.3 \mathrm{~s}, p<0.05$; D4: $\mathrm{CD} 3 \zeta^{+/+}: 50.9 \pm 15.4 \mathrm{~s}$; CD3 $\zeta^{-/-}: 103.2 \pm$ $13.3 \mathrm{~s}, p<0.05$, two-way ANOVA followed by Bonferroni post hoc test; Fig. $1 C$ ). No difference in velocity between the groups was observed, indicating that $\mathrm{CD} 3 \zeta^{+/+}$and $\mathrm{CD} 3 \zeta^{-/-}$mice showed comparable motor capacity (Fig. 1D). However, $\mathrm{CD} 3 \zeta^{+/+}$and $\mathrm{CD} 3 \zeta^{-/-}$mice showed a different search strategy profile to locate the escape tunnel during the training period. Initially, both wild-type and mutant mice mainly used the random strategy, in which mice explored many holes in an unsystematic fashion with many center crossings. On D1, the proportion of random strategy was $96.8 \pm 3.1 \%$ and $97.7 \pm 2.3 \%$ for $\mathrm{CD} 3 \zeta^{+/+}$and CD3 $\zeta^{-1-}$ mice, respectively (Fig. $1 E, F$ ). Starting from D2, CD3 $\zeta^{+/+}$mice transiently used the serial-search strategy, characterized by a methodical exploration of consecutive hole and thereafter progressively shifting to a spatial-search strategy, the most efficient strategy in which mice take the direct course to the escape tunnel. Although mutant mice were able to shift from the random to the serial strategy, they failed to use the spatial strategy consistently (Fig. $1 E, F$ ). On D4, the end of the training period, the spatial strategy was used by $40.6 \pm 14.9 \%$ and $15.9 \pm 5.1 \%$ of $\mathrm{CD} 3 \zeta^{+/+}(n=8)$ and $\mathrm{CD} 3 \zeta^{-1-}(n=11)$ mice, respectively $(p<0.05$; two-way ANOVA with Bonferroni post hoc test). Probe trials in which the escape box was removed were performed at D5 and D12. The working memory was assessed by counting the number of nose pokes into the target hole, which corresponds to the former location of the escape box, and to its adjacent holes. For both probe tests at D5 and D12, the group of $\mathrm{CD} 3 \zeta^{+/+}$mice showed a preference for the target hole compared with adjacent holes, indicating a good memory of that location (number of nose spokes for the target vs adjacent holes was $3.5 \pm$ 0.5 vs $0.7 \pm 0.2$ at D $5, p<0.001 ; 2.7 \pm 0.6$ vs $1.0 \pm 0.2$ at D12, $p<$ 0.05; two-way ANOVA with Bonferroni post hoc test; Fig. $1 G, H)$. In contrast, the group of $\mathrm{CD} 3 \zeta^{-/-}$mice showed no significant difference between the target and adjacent holes, suggesting impairment in working memory (number of nose spokes $=1.7 \pm$ 0.4 vs $0.7 \pm 0.2$ at $\mathrm{D} 5, p>0.05 ; 1.2 \pm 0.6$ vs $0.5 \pm 0.2$ at $\mathrm{D} 12, p>$ 


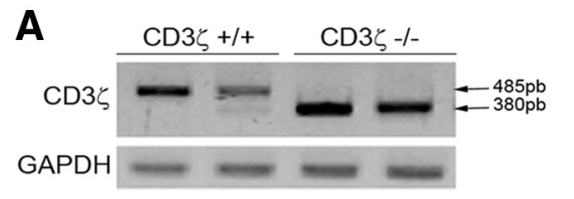

B

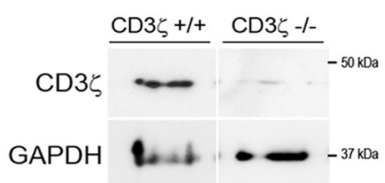

C

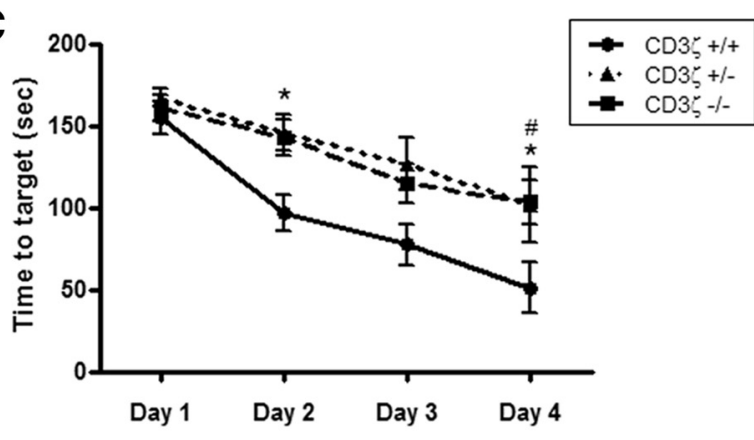

E

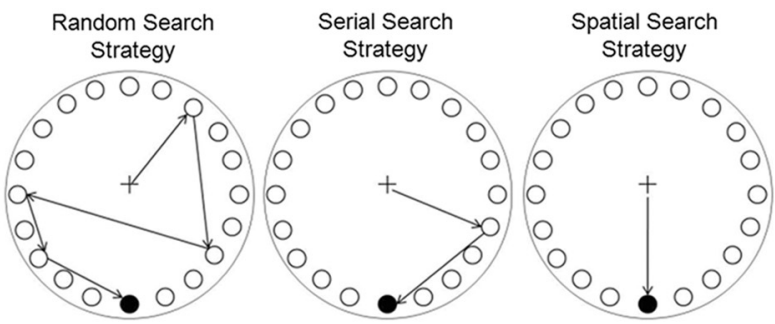

G Probe Test at Day 5

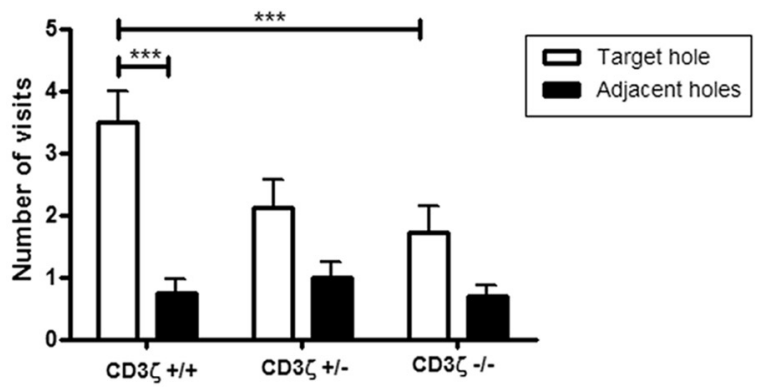

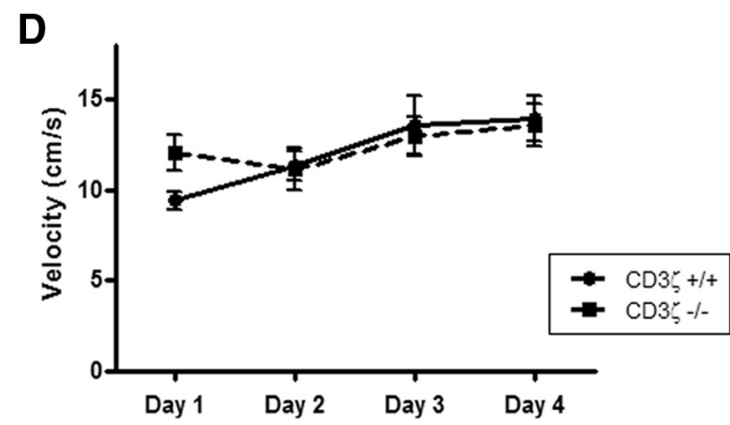

F

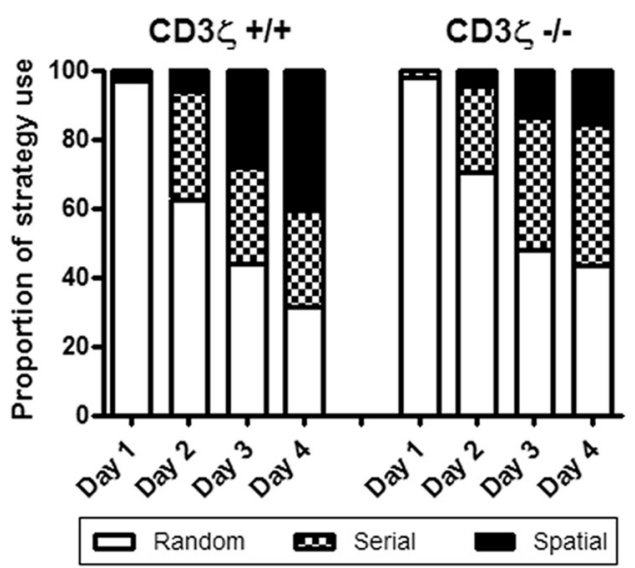

H Probe Test at Day 12

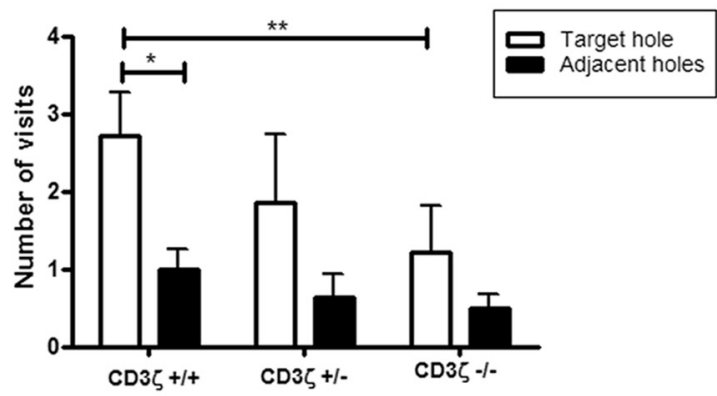

I

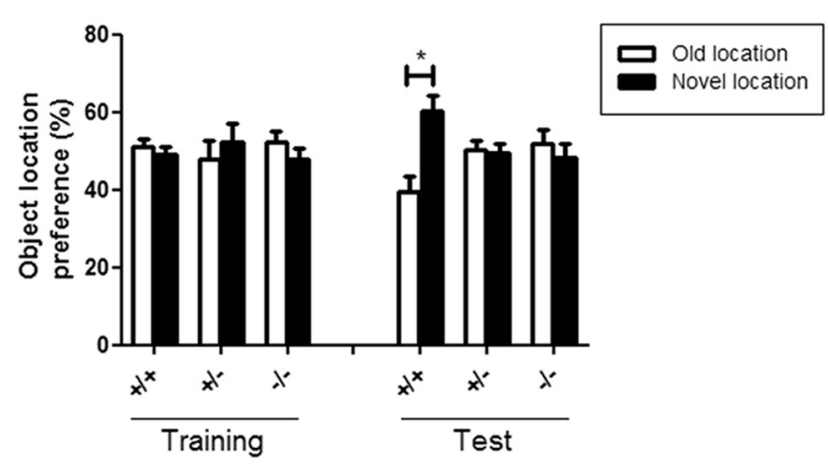

Figure 1. Impaired learning and memory in $\mathrm{CD} 3 \zeta^{-1-}$ mice. $A$, Identification of a truncated $\mathrm{CD} 3 \zeta \mathrm{mRNA}$ in $\mathrm{CD} 3 \zeta^{-1-}$ mouse hippocampus by PCR amplification. GAPDH amplification products indicated that PCR was performed on comparable level of CDNA. $\boldsymbol{B}$, Undetectable expression of $\mathrm{CD} 3 \zeta$ protein in $\mathrm{CD} 3 \zeta^{-/-}$mice. Brain lysates from $\mathrm{CD} 3 \zeta^{+/+}$(Figure legend continues.) 
0.05; two-way ANOVA with Bonferroni post hoc test). It has been reported that $\mathrm{CD} 3 \zeta^{-1-}$ mice exhibit developmental abnormalities of the visual system (Huh et al., 2000; Xu et al., 2010), which might in turn affect the visual abilities required to locate the escape hole using extramaze visual cues. In contrast, $\mathrm{CD} 3 \zeta^{+/-}$ mice showed an absence of retinal deficiency and an electroretinogram similar to that of $\mathrm{CD} 3 \zeta^{+/+}$mice (Xu et al., 2010). Therefore, the behavior of CD $3 \zeta^{+/-}$mice in the Barnes maze should entirely reflect the learning and memory performance of these mice without the interference of potential visual defects. During the course of the training period, $\mathrm{CD} 3 \zeta^{+/-}$mice exhibited a similar pattern to the $\mathrm{CD} 3 \zeta^{-1-}$ mice, with a significant increase in the time needed to reach the target hole at $\mathrm{D} 4$ compared with $\mathrm{CD} 3 \zeta^{+/+}$mice $\left(\mathrm{CD} 3 \zeta^{+/+} 50.9 \pm 15.4 \mathrm{~s}, \mathrm{CD} 3 \zeta^{+/-} 101.7 \pm 23.3 \mathrm{~s}, p<0.05\right.$; twoway ANOVA with Bonferroni post hoc test; Fig. $1 C$ ). As shown in Figure 1, $G$ and $H$, probe trials performed at D5 and D12 indicated that $\mathrm{CD} 3 \zeta^{+/-}$mice did not significantly differentiate between the target and adjacent holes. Compared with $\mathrm{CD} 3 \zeta^{+/+}$and $\mathrm{CD} 3 \zeta^{-/-}$ mice, the group of $\mathrm{CD} 3 \zeta^{+/-}$mice showed an intermediate phenotype, suggesting a gene-dose-dependent effect on memory. This result shows that the poor performance of the heterozygous $\mathrm{CD} 3 \zeta^{+/-}$mice in the Barnes maze was attributable to spatial learning and memory deficits and not to visual impairment.

Spatial learning and working memory were also assessed using a spatial location memory task. In this task, mice were habituated for $10 \mathrm{~min}$ to four different objects placed in a defined spatial orientation. Mice were tested $24 \mathrm{~h}$ later in a new object configuration in which two objects were moved to a novel location. Contacts with the "old location" and "novel location" objects were counted in both sessions. There were striking effects on reexploration of the displaced objects, in which a renewed interest (increased contacts) with the object was observed in wild-type but not in $\mathrm{CD} 3 \zeta^{-1-}$ and $\mathrm{CD} 3 \zeta^{+1-}$ mice, as indicated by the percentage of preference for the novel location compared with the old location $\left(\mathrm{CD} 3 \zeta^{+/+} 60.3 \pm 3.8 \%\right.$ vs $39.7 \pm 3.8, n=6, p<$ 0.05 ; $\mathrm{CD} 3 \zeta^{+/-} 49.5 \pm 2.3 \%$ vs $50.5 \pm 2.3 \%, n=5, p>0.05$; CD3 $\zeta^{-1-} 48.2 \pm 3.7 \%$ vs $51.8 \pm 3.7 \%, n=4, p>0.05$; two-way ANOVA with Bonferroni post hoc test). Together, these results support a role of $\mathrm{CD} 3 \zeta$ in spatial learning and working memory.

\footnotetext{
$\leftarrow$

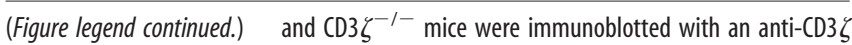
antibody. $\mathbf{C}-\boldsymbol{I}$, Cognitive behavior of $\operatorname{CD} 3 \zeta^{-/-}$mice in the Barnes maze task $(\boldsymbol{C}-\boldsymbol{H})$ and in the object location memory task (I). C, Performance measured as time to reach the target escape hole improved significantly in all groups over the course of training, but $\mathrm{CD}_{3} \zeta^{+/-}$and $\mathrm{CD} 3 \zeta^{-1-}$ groups required a significant increased amount of time to find the escape route. Data are mean $\pm \operatorname{SEM}(n=8-11) .{ }^{*} p<0.05\left(\mathrm{CD} 3 \zeta^{+/+}\right.$vs $\left.\mathrm{CD} 3 \zeta^{-/-}\right) ; \# p<0.05\left(\mathrm{CD} 3 \zeta^{+/+}\right.$vs $\left.\mathrm{CD}_{3} \zeta^{+/-}\right)$, two-way ANOVA with Bonferroni post hoc test. $D$, No difference in average velocities was found between $\mathrm{CD} 3 \zeta^{+/+}$and $\mathrm{CD} 3 \zeta^{-1-}$ mice. Data are mean \pm SEM $(n=8-11)$. $\boldsymbol{E}$, Schematic diagram depicting the search strategies used by the mice during the training period. $\boldsymbol{F}$, Percentage of random, serial, or spatial search strategy used by the mice over the course of training. Data are mean \pm SEM $(n=8-11)$. Compared with $\mathrm{CD} \zeta^{+/+}$mice, the proportion of spatial search strategy used by $\mathrm{CD} 3 \zeta^{-1-}$ mice is significantly reduced at $\mathrm{D} 4$ $(p<0.05$, two-way ANOVA with Bonferroni post hoc test). $\boldsymbol{G}, \boldsymbol{H}$, Probe tests were performed after the last training session on the Barnes maze at D5 $(\boldsymbol{G})$ and D12 $(\boldsymbol{H})$. Spatial memory was assessed by measuring the number of visits into the target hole and the two adjacent holes. $\mathrm{CD} 3 \zeta^{+/-}$and $\operatorname{CD} 3 \zeta^{-/-}$mice failed to show a preference for the target hole at both $\mathrm{D} 5$ and D12. Data are mean \pm SEM $(n=7-11) .{ }^{*} p<0.05 ;{ }^{* *} p<0.01 ;{ }^{* * *} p<0.001$, two-way ANOVA with Bonferroni post hoc test. $I, C D 3 \zeta^{-1+}$ and $\mathrm{CD}_{3} \zeta^{-/-}$failed to show preference for a novel object location in the object location memory task. The histogram represents the percentage of object location preference measured by the time spent in exploring objects in old or novel location/total time spent in exploring objects during a 10 min period. Data are mean \pm SEM $(n=4-6) .{ }^{*} p<0.05$, two-way ANOVA with Bonferroni post hoc test.
}

\section{Impaired spatial memory of $\mathrm{CD} 3 \zeta^{-/-}$mice is independent of} T-cell deficiency

Mice lacking $\mathrm{CD} 3 \zeta$ exhibited a marked decrease in circulating T cells (Liu et al., 1993; Love et al., 1993; Malissen et al., 1993), which might account for the cognitive impairment observed in $\mathrm{CD} 3 \zeta^{-1-}$ mice. Indeed, in mice with a normal immune system, depletion of $\mathrm{T}$ cells by administration of anti-CD4 antibodies or the immunosuppressive drug FTY720 resulted in cognitive impairment within $7 \mathrm{~d}$ in a water maze paradigm (Wolf et al., 2009; Derecki et al., 2010). Immunodeficient mice injected with splenocytes from wild-type counterparts showed a significant improvement of their performance on learning and memory tasks (Kipnis et al., 2004), whereas injection of T-cell-depleted splenocytes did not affect their performance, indicating that cognitive improvement was T-cell dependent (Brynskikh et al., 2008; Ron-Harel et al., 2008). To determine whether the T-cell deficiency of $\mathrm{CD} 3 \zeta^{-1-}$ mice might underlie their impaired memory performance, $\mathrm{CD} 3 \zeta^{-1-}$ mice were repopulated to a normal level of T cells by syngeneic BMT and subsequently evaluated for memory performance in the Barnes maze. Donor and recipient mice expressed different alleles of the CD45 and can therefore be differentiated by flow cytometry using this congenic marker. Irradiated $\mathrm{CD} 3 \zeta^{+/+}$and $\mathrm{CD} 3 \zeta^{-/-} \mathrm{CD} 45.2$ mice received $15 \times 10^{6}$ BMCs from C57BL/6 CD45.1 mice and immune cell reconstitution was analyzed by flow cytometry from blood samples at 14 , 42, and $56 \mathrm{~d}$ after transplantation (Fig. 2A). Importantly, all grafted mice developed multilineage mixed chimerism as assessed by the presence of monocytes and B cells (data not shown) as soon as $14 \mathrm{~d}$ after BMT and by the presence of T cells $42 \mathrm{~d}$ after BMT. We observed a progressive increase of donor-derived $\mathrm{T}$ cells $\left(\mathrm{CD} 45.2^{-}\right)$in both $\mathrm{CD} 3 \zeta^{+/+}$and $\mathrm{CD} 3 \zeta^{-/-}$mice (Fig. $2 A, B)$. In $\mathrm{CD} 3 \zeta^{+1+}$ mice, the T-cell population at D42 comprised $38.2 \pm 3.9 \%$ of donor-derived T cells (CD45.1-positive), whereas the remaining cells corresponded to CD45.2-positive $\mathrm{T}$ cells normally produced by $\mathrm{CD} 3 \zeta^{+/+}$mice. This percentage of chimerism ( $\sim 40 \%$ donor $/ 60 \%$ recipient) is expected for immunocompetent mice (Fehr et al., 2010). In contrast, in CD3 $\zeta^{-/-}$ mice originally devoid of circulating $\mathrm{T}$ cells, the majority of $\mathrm{T}$ cells were donor-derived CD45.1-positive T cells. At D42, $91.8 \pm 2.6 \%$ of total circulating $\mathrm{T}$ cells originated from the graft (Fig. 2B). Moreover, $42 \mathrm{~d}$ after BMT, the proportion of mature T cells (CD $3 \varepsilon$ - and TCR $\beta$-positive cells) in grafted $\mathrm{CD} 3 \zeta^{+/+}$and $\mathrm{CD} 3 \zeta^{-1-}$ mice was similar to naive $\mathrm{CD} 3{ }^{+1+}$ mice. This result indicated that the BM cells engrafted efficiently and that transplanted $\mathrm{CD} 3 \zeta^{-1-}$ mice develop normal level of donor-derived $\mathrm{T}$ cells $\left(\mathrm{CD} 3 \varepsilon^{+} 25.99 \pm 1.56 \%\right.$ and $18.61 \pm 1.37 \%$ of total cells for grafted $\mathrm{CD} 3 \zeta^{+1+}$ and grafted $\mathrm{CD} 3 \zeta^{-1-}$ mice, respectively; $\mathrm{TCR} \beta^{+} 26.51 \pm 1.62 \%$ and $20.50 \pm 1.42 \%$ of total cells for grafted $\mathrm{CD} 3 \zeta^{+/+}$and grafted $\mathrm{CD} 3 \zeta^{-/-}$mice, respectively; $n=$ $10-11, p>0.05$; Kruskal-Wallis test with Dunn post hoc test; Fig. $2 C, D)$. Working memory was assessed in the Barnes maze at D42 after BMT. Despite T-cell replenishment, grafted CD3 $\zeta^{-1-}$ mice still showed no preference for the target hole compared with the adjacent holes (Fig. 2E). Notably, comparable levels of T cells were observed in $\mathrm{CD} 3 \zeta^{+/+}$and $\mathrm{CD} 3 \zeta^{-1-}$ mice at the end of the behavioral session at D56, suggesting that the efficiency of T-cell repopulation remained similar in both groups during the entire behavioral test period (Fig. 2A). The failure of T-cell replenishment to restore memory performance in $\mathrm{CD} 3 \zeta^{-1-}$ mice suggested that the impaired learning and working memory of $\mathrm{CD} 3 \zeta^{-1-}$ mice was likely independent of the T-cell deficiency. 
A
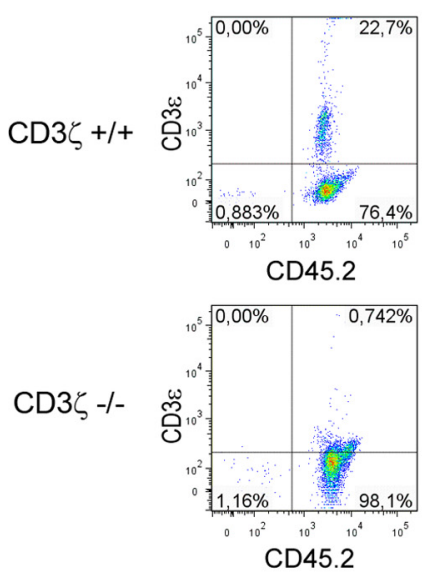

C

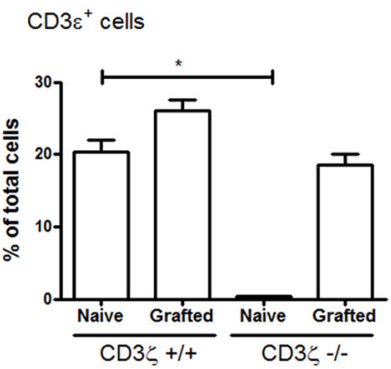

\section{Naive}
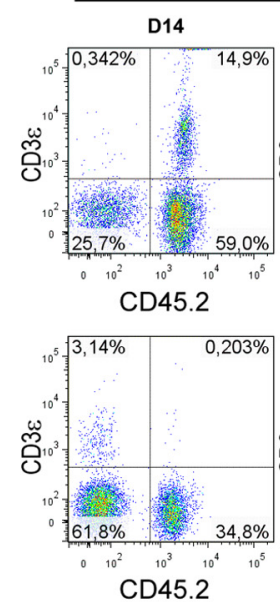

D

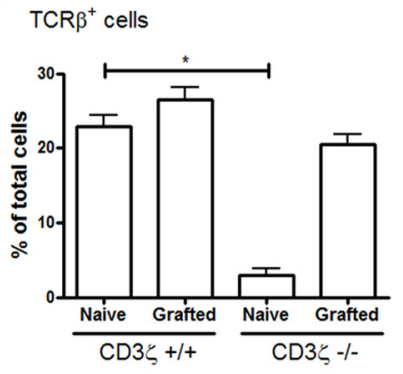

Grafted (Days postgraft)
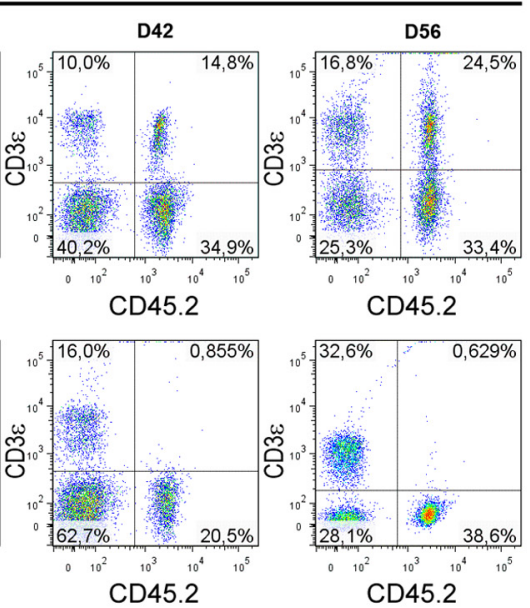

E

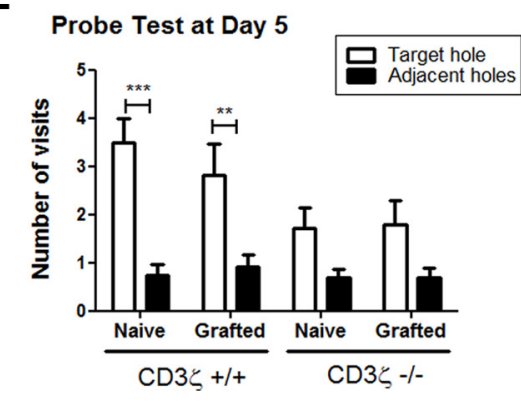

B

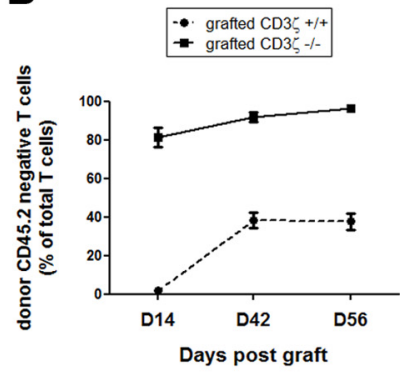

Figure 2. Impaired spatial memory of $\mathrm{CD} 3 \zeta^{-/-}$mice is independent of T-cell deficiency. $A$, Analysis of T-cell population in $\mathrm{CD} 3 \zeta^{+/+}$and $\mathrm{CD} 3 \zeta^{-/-}$mice before (naive) and after (grafted) BMT at D14, D42, and D56. Representative flow-cytometry dot plots of peripheral mononuclear cells stained for CD3\& (a T-cell marker) and CD45.2 (a recipient cell marker). Number in the corner of each quadrant corresponds to the percentage of the corresponding cell population. $B$, Quantification of the proportion of donor T cells (CD45.2-negative) in the blood of $\operatorname{CD3} \zeta^{+/+}$and $C D 3 \zeta^{-/-}$mice 14,42 , and $56 \mathrm{~d}$ after BMT. C, D, Percentage of T cells quantified with the T-cell markers $\operatorname{CD} 3 \boldsymbol{\varepsilon}(\boldsymbol{C})$ and TCR $\beta(\boldsymbol{D})$ in peripheral blood cells from 12 -week-old $\operatorname{CD} 3 \zeta^{+/+}$and $\mathrm{CD} 3 \zeta^{-1-}$ mice $(n=$ 7-10). Data are mean \pm SEM. ${ }^{*} p<0.05$, Kruskal-Wallis with Dunn's multiple-comparison tests. Comparisons were made with the naive $\mathrm{CD} \zeta^{+/+}$group. $E$, Memory performance of grafted $\mathrm{CD} 3 \zeta^{+/+}$and $\mathrm{CD} 3 \zeta^{-/-}$mice in the Barnes maze task analyzed $42 \mathrm{~d}$ after BMT. Probe trials were performed at $\mathrm{D} 5$ of the test, after $4 \mathrm{~d}$ of training. Spatial memory was assessed by measuring the number of visits into the target hole and the two adjacent holes. Naive and grafted $\mathrm{CD}_{3} \zeta^{-1-}$ mice failed to show a preference for the target hole. Data are mean \pm SEM $(n=8-11)$. ${ }^{* *} p<0.001$; ${ }^{* *} p<0.01$, two-way ANOVA with Bonferroni post hoc test.

\section{Decrease of synaptic GluN2A subunit and GluN2A-PSD95 interaction in $\mathrm{CD} 3 \zeta^{-1-}$ mice}

In the CNS, $\mathrm{CD} 3 \zeta$ is mostly expressed in neurons (Baudouin et al., 2008; Xu et al., 2010; Angibaud et al., 2011). In cortical cultured neurons from $\mathrm{CD} 3 \zeta^{+/+}$mice, $\mathrm{CD} 3 \zeta$ immunoreactivity is distributed in clusters mainly overlapping the glutamatergic synaptic marker PSD95, in agreement with previous data from rat hippocampal cultured neurons (Fig. 3A; Baudouin et al., 2008). Moreover, no overlap was observed between $\mathrm{CD} 3 \zeta$ and the GABAergic synaptic marker GAD, indicating the preferential localization at glutamatergic synapses (Fig. 3B). No CD3 $\zeta$ staining was observed in $\mathrm{CD} 3 \zeta^{-1-}$ neurons, supporting the specificity of the immunostaining provided by the $\mathrm{CD} 3 \zeta$ antibody (Fig. $3 C$ ). To further detail the synaptic localization of $\mathrm{CD} 3 \zeta$, neurons immunolabeled for $\mathrm{CD} 3 \zeta$ and either the postsynaptic NMDA receptor (NMDAR) subunit GluN1 or the presynaptic protein SV2 were analyzed by confocal microscopy to achieve a $3 \mathrm{D}$ reconstruction. The representation of $3 \mathrm{D}$ reconstruction indicated an overlap of the $\mathrm{CD} 3 \zeta$ and GluN1 immunolabeling, whereas $\mathrm{CD} 3 \zeta$ clusters were mostly apposed to SV2 clusters without any detectable overlap, supporting a postsynaptic localization of $\mathrm{CD} 3 \zeta$ in cortical neurons (Fig. 3D). The synaptic localization of $\mathrm{CD} 3 \zeta$ was further confirmed by immunoblot analysis from rat brains, in which the expression of $\mathrm{CD} 3 \zeta$ was detected in the synaptic mem- brane fraction (Fig. 3E). We next assessed by immunofluorescence studies in cortical neuron cultures whether the lack of $\mathrm{CD} 3 \zeta$ would affect the distribution of glutamate receptors. Immunostaining for NMDAR (Fig. 4A) and AMPA glutamate receptor (AMPAR) subunits and for the scaffolding molecule PSD95 were performed at $15 \mathrm{DIV}$ in $\mathrm{CD} 3 \zeta^{+/+}$and $\mathrm{CD} 3 \zeta^{-1-}$ cultured neurons. For each examined synaptic protein, the total number of clusters along dendrites, including synaptic and extrasynaptic clusters, was similar in $\mathrm{CD} 3 \zeta^{+/+}$and $\mathrm{CD} 3 \zeta^{-1-}$ neurons (Fig. $4 B$ ). In contrast, the number of synaptic clusters, quantified by double labeling with the presynaptic protein Synapsin I, showed that the proportion of synaptic NMDAR subunit GluN2A was reduced in $\mathrm{CD} 3 \zeta^{-1-}$ neurons compared with $\mathrm{CD} 3 \zeta^{+/+}$neurons $(56.02 \pm 3.27 \%$ and $39.48 \pm 3.87 \%$ of total clusters in $\mathrm{CD} 3 \zeta^{+/+}$and $\mathrm{CD} 3 \zeta^{-1-}$ neurons, respectively, $n=30$, $p<0.01$, Student's $t$ test; Fig. $4 A, C)$. The number of synaptic clusters for GluN1, GluN2B, AMPAR subunit GluA1, and PSD95 was unchanged (Fig. 4C). In agreement with these in vitro data, Western blots performed with synaptosome-enriched fractions from mice brain indicated that the amount of GluN2A was significantly reduced in mutant mice compared with $\mathrm{CD} 3 \zeta^{+/+}$ (GluN2A signal intensity normalized to GAPDH level was $338.5 \pm 43.4$ in $\mathrm{CD} 3 \zeta^{+/+}$mice; $164.7 \pm 7.7 \%$ in $\mathrm{CD} 3 \zeta^{-1-}$ mice, $n=5, p<0.01$; two-way ANOVA with Bonferroni post hoc test), 

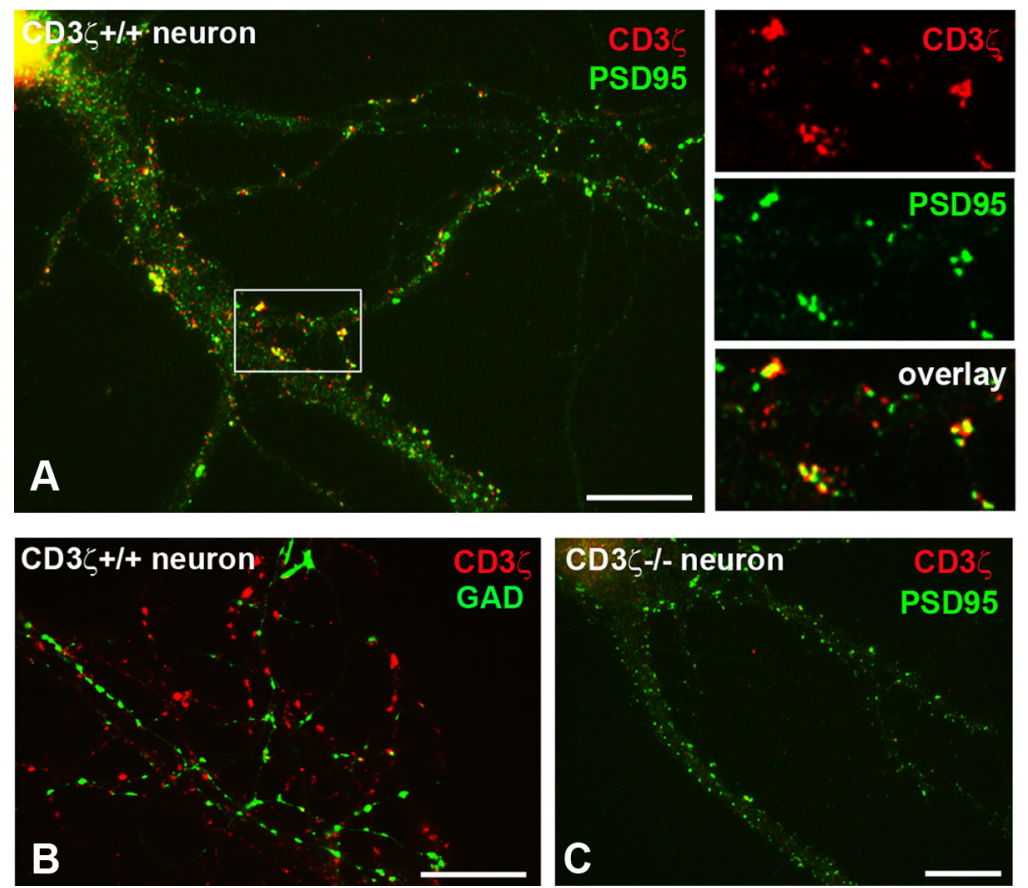

D
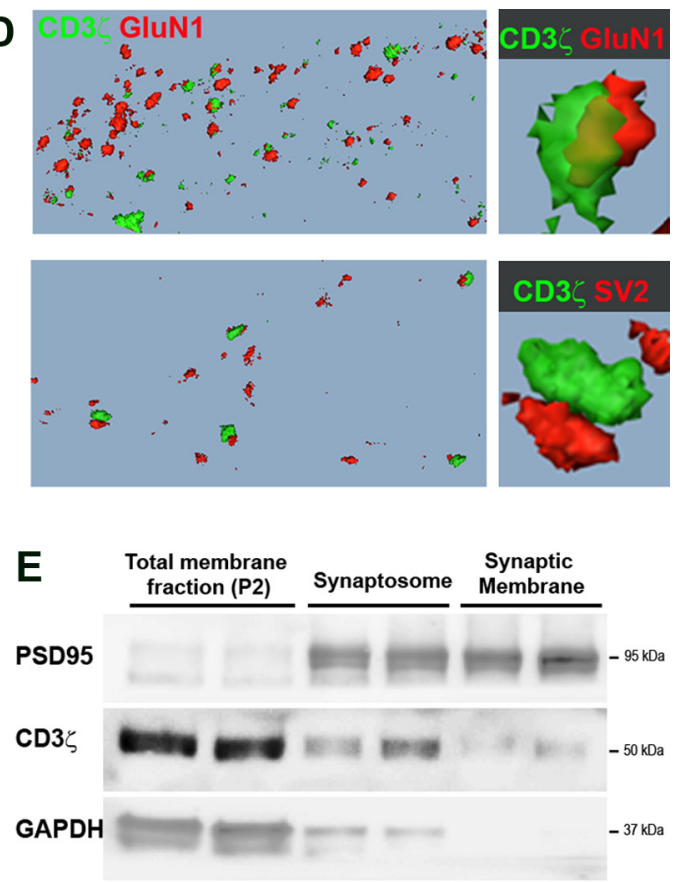

Figure 3. CD3 $\zeta$ localizes to glutamatergic postsynaptic sites. $A$, Cortical cultures of CD $3 \zeta^{+/+}$neurons were fixed at 15 DIV and immunolabeled for CD3 $\zeta$ (red) and the glutamatergic postsynaptic marker PSD95 (green). CD3 $\zeta$ clusters were distributed along dendritic processes and mainly colocalized with PSD95 clusters as shown at higher magnification of the boxed region. $\boldsymbol{B}$, Double labeling of $C D 3 \zeta$ with GABAergic synaptic marker GAD shows no overlap between $C D 3 \zeta$ and GAD clusters. $C$, Cultures of $C D 3 \zeta{ }^{-1-}$ cortical neurons show an absence of CD3 $\zeta$ staining. $D$, Representation of $3 D$ confocal microscopy reconstruction from cultured neurons immunolabeled for CD3 $\zeta$ (green) and the glutamatergic postsynaptic marker GluN1 (red) or the presynaptic marker SV2 (red). $\boldsymbol{E}$, Western blot analysis of brain homogenate, synaptosome, and synaptic membrane prepared from adult rat brain. For each sample, $20-40 \mu \mathrm{g}$ of proteins was loaded on a $10 \%$ SDS-PAGE under

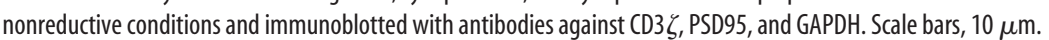

whereas no modification of GluN1 and GluN2B expression level was observed (Fig. $4 D, E$ ). Interestingly, no significant change in GluN1, GluN2B, or GluN2A subunit levels was detected in the whole membrane fraction (Fig. 4D,E). These results suggest that the lack of $\mathrm{CD} 3 \zeta$ selectively affects synaptic accumulation of GluN2A without interfering with the cellular expression levels. We next investigated whether $\mathrm{CD} 3 \zeta$ would interact with glutamate receptors by performing co-IP experiments. Mice brain homogenates solubilized in $1 \%$ Triton X-100 were immunoprecipitated with a monoclonal $\mathrm{CD} 3 \zeta$ antibody and the immunoprecipitates were analyzed by immunoblot for GluN2A and GluA1. As shown in Figure $4 F$, only GluN2A was detected in the protein complex. Control experiments using a nonspecific IgG or performed with $\mathrm{CD} 3 \zeta^{-1-}$ brain lysate showed an absence of GluN2A signal in the immunoprecipitated complex, indicating the specificity of the interaction between $\mathrm{CD} 3 \zeta$ and GluN2A. Having shown that $\mathrm{CD} 3 \zeta$ interacts with GluN2A and that its absence downregulates the synaptic localization of GluN2A, we speculated that $\mathrm{CD} 3 \zeta$ may facilitate the association of NMDARs with the membrane-associated guanylate kinase (MAGUK) protein PSD95, a major scaffolding molecule involved in the cell surface stabilization and synaptic localization of NMDARs (Kornau et al., 1995; Steigerwald et al., 2000; Lavezzari et al., 2003). To test this hypothesis, the association between PSD95 and its preferential interacting subunit GluN2A was studied by co-IP assay in $\mathrm{CD} 3 \zeta^{+/+}$and $\mathrm{CD} 3 \zeta^{-/-}$mouse brain lysates. The signal intensity of the co-IP PSD95 was weaker in $\mathrm{CD} 3 \zeta^{-1-}$ than in $\mathrm{CD} 3 \zeta^{+/+}$ brain lysate, indicating that the interaction between PSD95 and GluN2A is disrupted in CD3 $\zeta^{-1-}$ mice (signal co-IP PSD95 in arbitrary units: $5.2 \pm 2.5$ and $0.4 \pm 0.4$ in $\mathrm{CD} 3 \zeta^{+/+}$and $\mathrm{CD} 3 \zeta^{-1-}$ mice, respectively, $p<0.05$, Mann-Whitney test; Fig. $4 G, H)$. These experiments identify $\mathrm{CD} 3 \zeta$ as a novel interacting partner of GluN2A. This interaction seems to consolidate the association between GluN2A and PSD95, which might consequently promote the synaptic expression of GluN2A-containing NMDARs in neurons.

\section{Defect in activity-dependent CaMKII autophosphorylation in $\mathrm{CD} 3 \zeta^{-1-}$ neurons}

In addition to the synaptic anchoring of NMDARs, PSD95 is critical to assembly of the NMDA receptor-associated protein complex, thereby supporting the functional coupling of NMDARs with downstream signaling at synapses (Sheng and Kim, 2011; Sanz-Clemente et al., 2013). We thus investigated whether the lack of $\mathrm{CD} 3 \zeta$ might affect downstream signaling pathways at glutamatergic synapses. We have reported previously that $\mathrm{CD} 3 \zeta$ interacts with the ephrin receptor EphA4 and acts downstream of an ephrinA1/EphA4 pathway to mediate early neuronal morphogenesis (Angibaud et al., 2011). In mature neurons, EphA4 is a component of the glutamatergic synapses and is involved in the regulation of dendritic spine morphology and hippocampal synaptic plasticity (Grunwald et al., 2004; Murai and Pasquale, 2004; Inoue et al., 2009). Increased synaptic activity induces the processing of EphA4 by $\gamma$-secretase, resulting in the formation of a cleaved EphA4 intracellular domain (EICD), which has the ability to enhance the formation of dendritic spines (Inoue et al., 2009). We postulated that $\mathrm{CD} 3 \zeta$ might be part of a NMDA-EphA4 receptor protein complex and might therefore regulate the level of EphA4 processing in a coordinated manner with synaptic activation. We thus examined whether the lack of $\mathrm{CD} 3 \zeta$ would alter the level of EICD. Western blot analysis of EICD showed no difference in brain lysates from $\mathrm{CD} 3 \zeta^{+1+}$ and $\mathrm{CD} 3 \zeta^{-1-}$ mice (Fig. $5 A, B$ ). The processing of EphA4 was further analyzed in primary cortical neuron cultures in which the spon- 


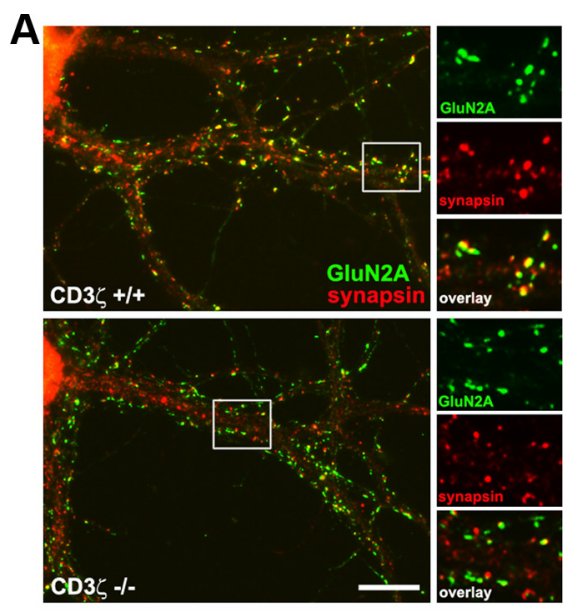

B
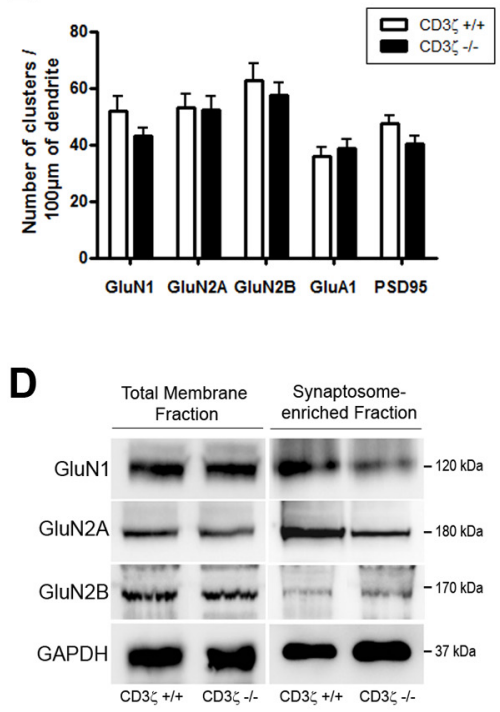

C
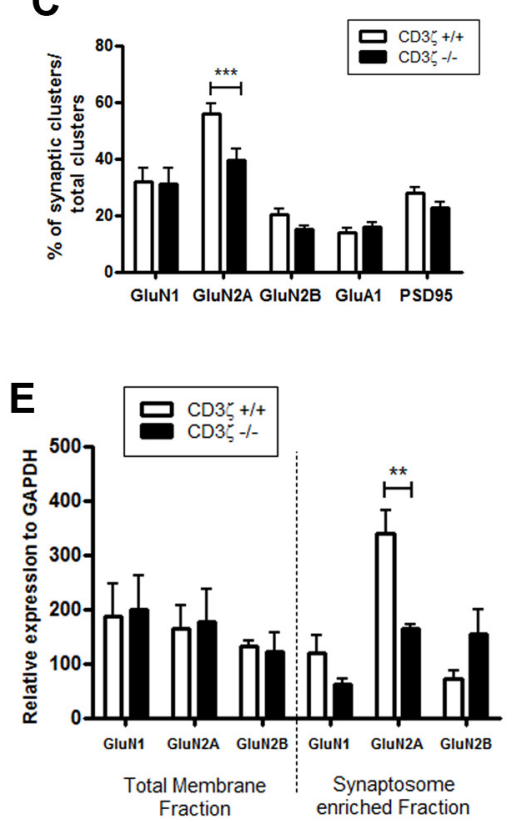

F

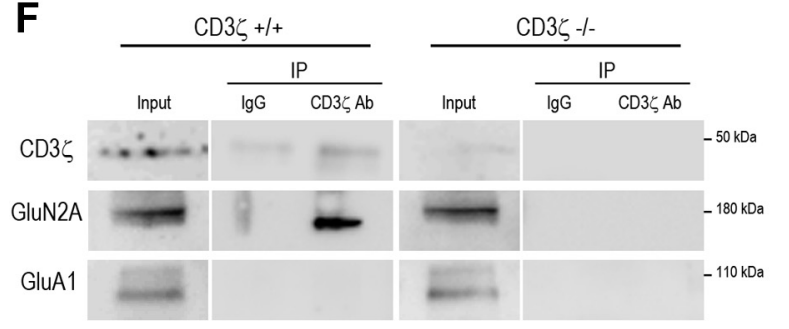

G

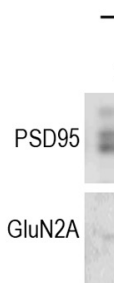

CD3 $\zeta+/+$

Input $\frac{\mathbb{I P}}{\lg G \quad \text { GluN2A Ab }}$

CD3 - -

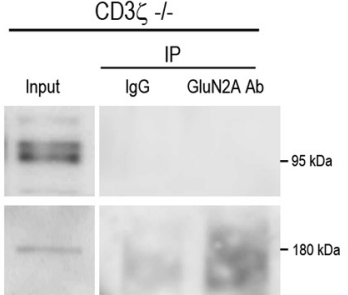

H

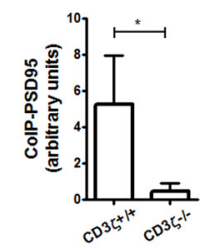

Figure 4. CD3 $\zeta$ is required for the synaptic localization of GluN2A and the GluN2A-PSD95 interaction. $A$, Representative images of 15 DIV cultured cortical neurons from CD3 $\zeta^{+/+}$and $C D 3 \zeta^{-/-}$ mice double labeled with GluN2A and Synapsin I. Scale bar, $10 \mu \mathrm{m}$. B, The number of GluN1, GluN2A, GluN2B, GluA1, and PSD95 clusters per length of dendrite was measured in 15 DIV CD3 $\zeta^{+/+}$ and $C D 3 \zeta^{-/-}$cultured cortical neurons immunostained for each protein $(n=3-4)$. C, Levels of synaptic GluN1, GluN2A, GluN2B, GluA1, and PSD95 clusters in 15 DIV CD3 $\zeta^{+/+}$and CD3 $\zeta^{-/-}$ cultured cortical neurons immunostained by double labeling of each postsynaptic protein with the presynaptic protein synapsin I. Data are mean $\pm \operatorname{SEM}(n=3-4)$. ${ }^{* * *} p<0.01$, Mann-Whitney test. $\boldsymbol{D}$, Western blot analysis of NMDAR subunits in total membrane fraction and synaptosome-enriched fraction from $\mathrm{CD} \zeta^{+/+}$and $\mathrm{CD} \zeta^{-/-}$mouse brains. $\boldsymbol{E}$, Quantification of the expression of NMDAR subunits in the total membrane fraction and synaptosome-enriched fraction of $\mathrm{CD} 3 \zeta^{+/+}$and $C D 3 \zeta^{-/-}$mouse brains normalized to GAPDH. Data are mean \pm SEM $(n=4$ for each group). ${ }^{* *} p<0.01$, Mann-Whitney test. $\boldsymbol{F}$, GluN2A, but not GluA1, is c0-immunoprecipitated with CD3 $\zeta$ from $C D 3 \zeta^{+/+}$mice brain lysate. Mice brain membrane homogenates solubilized in $1 \%$ Triton X-100 were immunoprecipitated with CD3 $\zeta$ antibody. The immunoprecipitates were resolved by SDS-PAGE and probed with GluN2A or GluA1 antibodies. GluN2A is not detected in protein complex immunoprecipitated from $\mathrm{CD} 3 \zeta^{-1-}$ mice brain lysate. Input lanes contain $5 \%$ of extract used for IP. G, Disruption of GluN2A-PSD95 interaction in $\mathrm{CD}^{2} \zeta^{-1-}$ mice. CD3 $\zeta^{+/+}$and CD3 $\zeta^{-1-}$ mice brain membrane homogenates solubilized in 1\% Triton X-100 were immunoprecipitated with GluN2A antibody and immunoblotted with a PSD95 antibody. Input lanes contain $5 \%$ of extract used for IP. H, Quantification of the co-IP PSD95 signal with GluN2A antibody from mouse brain lysates. Signal intensity of co-immunoprecipitated PSD 95 was normalized to signal intensity of PSD95 input, divided by signal intensity of IP GluN2A. Values are mean \pm SEM $(n=4) .{ }^{*} p<0.05$, Mann-Whitney test.

taneous synaptic activity was increased by application of the adenylate cyclase activator forskolin and the phosphodiesterase inhibitor rolipram (F/R), a treatment previously shown to induce EICD production (Inoue et al., 2009). This treatment enhanced the processing of EphA4 similarly in $\mathrm{CD} 3 \zeta^{+/+}$and $\mathrm{CD} 3 \zeta^{-/-}$ neurons (Fig. $5 C, D$ ), indicating that $\mathrm{CD} 3 \zeta$ is likely not involved in the synaptic-activity-induced processing of EphA4.

CaMKII is a key synaptic signaling molecule at glutamatergic synapses and has a well documented role in the induction of LTP (Lisman et al., 2012). The current model is that the opening of NMDARs during the induction of LTP leads to calcium entry that triggers activation of CaMKII. This calcium elevation induces the synaptic translocation of CaMKII and its binding to NMDARs. Then, the autophosphorylation at the threonine-286 (T286) in the $\alpha$-isoform switches the kinase into an active conformation that persists even after the calcium concentration falls to baseline levels. The autophosphorylation of CaMKII is a prerequisite for changes in synaptic strength, such as LTP (Giese et al., 1998; Hudmon and Schulman, 2002). We investigated whether the synaptic translocation and level of autophosphorylated CaMKII would be affected by the lack of CD3 $\zeta$. NMDA-dependent synaptic plasticity was induced in cortical neuron cultures using a Gly-LTP protocol. Application of glycine in the absence of $\mathrm{Mg}^{2+}$ induces the selective activation of synaptic NMDARs ( $\mathrm{Lu}$ et al., 2001), resulting in LTP manifest by long-lasting increase in mEPSC amplitude and frequency (Lu et al., 2001; Kopec et al., 2006) and synaptic translocation of CaMKII and GluA1 (Liao et al., 2001; Lu et al., 2001; Oh and Derkach, 2005; Sharma et al., 2006). In CD $3 \zeta^{+/+}$neurons, Gly-LTP stimulates the translocation of CaMKII from dendritic shafts to spines by more than 2-fold, whereas this effect was abolished in $\mathrm{CD} 3 \zeta^{-1-}$ neurons (control vs Gly-LTP, $p<0.001$ for CD3 $\zeta$ and $p>0.05$ for $\mathrm{CD} 3 \zeta^{-1-}$, two-way ANOVA followed by Bonferroni post hoc test; Fig. $6 A, B)$. Moreover, increase of autophosphorylated CaMKII at T286 was significantly induced by Gly-LTP in $\mathrm{CD} 3 \zeta^{+/+}$but absent in CD3 $\zeta^{-/-}$neurons (control vs Gly-LTP, $p<0.05$ for $\mathrm{CD} 3 \zeta^{+/+}$and $p>0.05$ for $\mathrm{CD} 3 \zeta^{-/-}$, two-way ANOVA followed by Bonferroni post hoc test; Fig. $6 C, D$ ). A key 

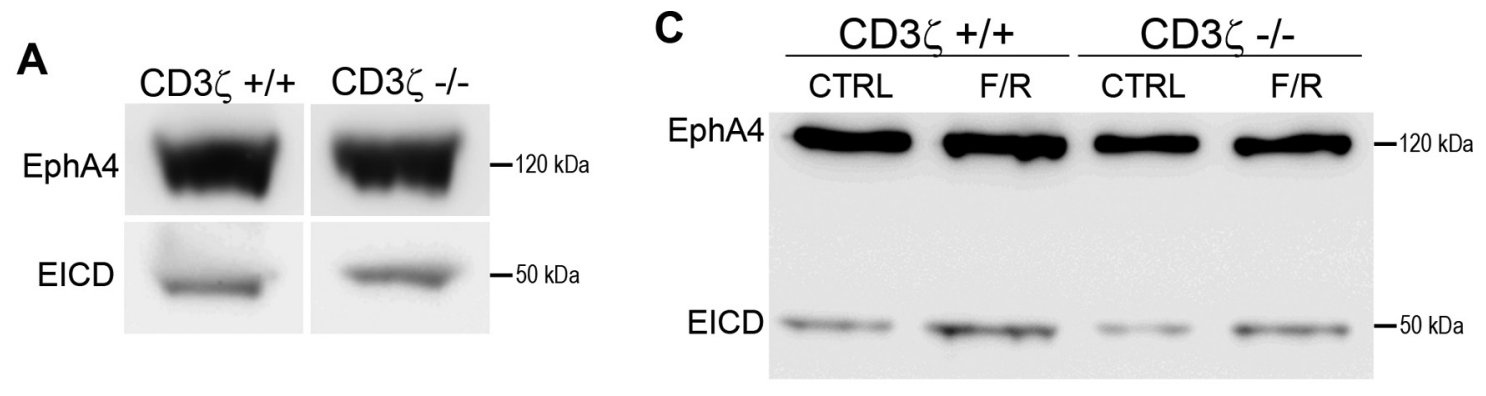

B

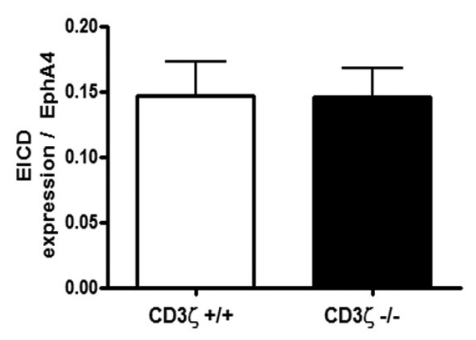

D

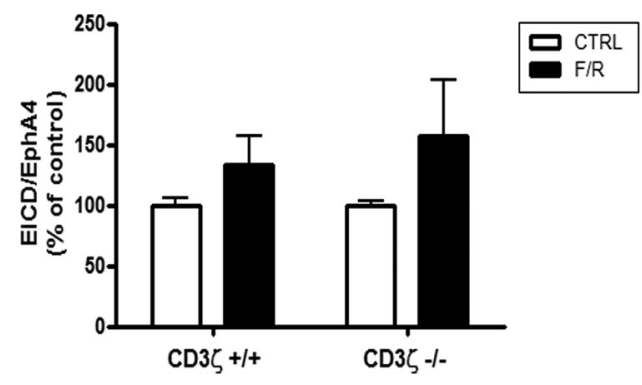

Figure 5. CD3 $\zeta$ is not required for the activity-induced processing of EphA4. A, Western blot analysis of the cleaved EphA4 intracellular domain EICD in $C D 3 \zeta^{+/+}$and $C D 3 \zeta^{-1-}$ mouse brains. Forebrain form $\mathrm{CD} 3 \zeta^{+/+}$and $\mathrm{CD} 3 \zeta^{-1-}$ mice were solubilized in RIPA buffer and analyzed by Western blot using an EphA4 antibody. B, For quantification, EICD signals were divided by EphA4 signals $(n=4)$. C, Western blot analysis of the activity-induced increase of cleaved EphA4 intracellular domain EICD in CD3 $\zeta^{+/+}$and CD3 $\zeta^{-/-}$cultured cortical neurons. Cultured neurons at 15 DIV were incubated for $16 \mathrm{~h}$ with DMSO (CTRL) or F/R, and EphA4 processing was assessed by Western blot using an EphA4 antibody. D, Quantification of the EICD/EphA4 ratio (percentage of control). Data are mean $\pm \operatorname{SEM}(n=3)$.

event to maintain the synaptic localization and active conformation of CaMKII is the binding of CaMKII to several postsynaptic density proteins, among which the GluN2 subunits of the NMDAR appear to be of primary importance. The interaction of CaMKII with the GluN2A and GluN2B subunits was assessed by co-IP from $\mathrm{CD} 3 \zeta^{+/+}$and $\mathrm{CD} 3 \zeta^{-/-}$mice brain lysates. CaMKII underwent co-IP with GluN2A from $\mathrm{CD} 3 \zeta^{+/+}$mice brain but not from $\mathrm{CD} 3 \zeta^{-1-}$ mice brain (signal coIP CaMKII in arbitrary units: $87.3 \pm 60.6$ and $0.1 \pm 0.1$ in $\mathrm{CD} 3 \zeta^{+/+}$and $\mathrm{CD} 3 \zeta^{-1-}$, respectively, $p<0.05$, Mann-Whitney test; Fig. $6 E, F)$. In contrast, CaMKII was immunoprecipitated with GluN2B at a similar level in $\mathrm{CD} 3 \zeta^{+/+}$and $\mathrm{CD} 3 \zeta^{-/-}$brain homogenates (signal coIP CaMKII in arbitrary units: $16.6 \pm 12.1$ and $10.1 \pm 3.3$ in $\mathrm{CD} 3 \zeta^{+/+}$and $\mathrm{CD} 3 \zeta^{-/-}$, respectively, $p>0.05$, Mann-Whitney test; Fig. $6 E, F)$. These data suggest that the reduced-activityinduced synaptic accumulation and phosphorylation at T286 of CaMKII in $\mathrm{CD} 3 \zeta^{-1-}$ neurons likely results from a defective CaMKII-GluN2A interaction.

\section{Lack of $\mathrm{CD} 3 \zeta^{-1-}$ impairs activity-dependent synaptic} recruitment of the AMPAR subunit GluA1

The decrease of CaMKII activation in $\mathrm{CD} 3 \zeta^{-/-}$neurons might affect AMPAR channel properties and trafficking. Activated CaMKII promotes the enhancement of AMPA-mediated transmission during LTP through two main processes. One process increases the conductance of AMPARs through a CaMKIIdependent phosphorylation of GluA1, mainly at Ser831 (S831) (Kristensen et al., 2011). The second process is the insertion of AMPARs into synapses. This mechanisms is thought to be achieved through the CaMKII-dependent phosphorylation of the GluA1 auxiliary subunit stargazin, which in turn allows AMPAR to bind to PSD95, resulting in the anchoring of AMPARs at the synapse (Tomita et al., 2005; Opazo et al., 2010). We thus investigated whether activity-dependent GluA1 phosphorylation at
S831 or GluA1 recruitment at synaptic sites would be affected by

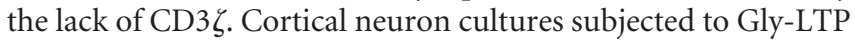
were analyzed by Western blot for the level of phosphorylated GluA1 at S831 using a phospho-S831 GluA1 antibody. The GlyLTP protocol induced an increase of the phospho-S831 GluA1 similarly in $\mathrm{CD} 3 \zeta^{+/+}$and $\mathrm{CD} 3 \zeta^{-/-}$neurons (Fig. $7 A, B$ ). The effect of Gly-LTP on the synaptic recruitment of GluA1 was achieved by immunofluorescence studies. Neurons were immunolabeled for GluA1 and the postsynaptic marker PSD95. Synaptic GluA1 was defined as GluA1 clusters colocalized with PSD95 clusters. Gly-LTP induced a $>2$-fold increase of synaptic GluA1 in $\mathrm{CD} 3 \zeta^{+/+}$neurons compared with mock-stimulated control $(p<0.01$, two-way ANOVA with Bonferroni post hoc test; Fig. $7 C, D)$. In contrast, $\mathrm{CD} 3 \zeta^{-1-}$ neurons failed to undergo the synaptic accumulation of GluA1 upon Gly-LTP $(p>0.05$, two-way ANOVA with Bonferroni post hoc test; Fig. $7 C, D$ ). As a control, PSD95 protein clustering was unaffected by genotype or stimulation (Fig. 7E). These results suggest that the deficiency of CaMKII autophosphorylation in $\mathrm{CD} 3 \zeta^{-1-}$ neurons preserves the signaling pathway required for the GluA1 phosphorylation at S831 but affects the synaptic recruitment of GluA1.

\section{Discussion}

This study identified for the first time the immunoreceptorassociated protein $\mathrm{CD} 3 \zeta$ as a key mediator in learning and memory. We found that the impaired cognitive behavior of $\mathrm{CD} 3 \zeta^{-1-}$ mice is independent of T-cell deficiency, but associated with major alterations of glutamatergic synapses. Specifically, our data showed that $\mathrm{CD} 3 \zeta$ promotes GluN2A synaptic localization and the formation of GluN2A-CaMKII complexes. Moreover, CD3 $\zeta$ is required for NMDA-dependent CaMKII activation and for the synaptic recruitment of the AMPAR subunit GluA1 (Fig. 8). Together, these results support the model that the procognitive function of $\mathrm{CD} 3 \zeta$ may be mediated through its involvement in 
the NMDAR downstream signaling pathway leading to CaMKII-dependent LTP induction.

Our study showed that $\mathrm{CD} 3 \zeta$-deficient mice exhibited impaired learning behavior and working memory as examined by spatial learning and memory tasks in the Barnes maze and a spatial location memory task. In $\mathrm{CD} 3 \zeta^{-1-}$ mice, the level of circulating $\mathrm{T}$ cells is dramatically reduced (Liu et al., 1993; Love et al., 1993; Malissen et al., 1993; Ohno et al., 1993). Given the importance of peripheral circulating $\mathrm{T}$ cells in cognitive functions and neural plasticity (Yirmiya and Goshen, 2011; Kipnis et al., 2012), CD3 $\zeta^{-1-}$ mice were repopulated to a normal level of $\mathrm{T}$ cells by syngeneic BMT. This approach did not restore the cognitive deficit of $\mathrm{CD} 3 \zeta^{-1-}$ mice, indicating that replenishment with wild-type $\mathrm{T}$ cells had no influence on cognitive behavior of CD3 $\zeta^{-/-}$mice. This result suggests that the cognitive deficits of $\mathrm{CD} 3 \zeta^{-1-}$ mice primarily resulted from the absence of $\mathrm{CD} 3 \zeta$ in neurons. However, it remains possible that grafted $\mathrm{T}$ cells exerted a beneficial, but less prevalent, effect on memory, which could have been masked by the dominant direct effect of the absence of CD3 $\zeta$ on neuronal functions.

We found a postsynaptic enrichment of $\mathrm{CD} 3 \zeta$ at glutamatergic synapses and defects in Gly-LTP in CD $3 \zeta^{-1-}$ neurons, suggesting essential postsynaptic functions of $\mathrm{CD} 3 \zeta$ at glutamatergic synapses, in agreement with previous studies in the hippocampus and the retina (Huh et al., 2000; Xu et al., 2010). We now delineate a mechanism by which $\mathrm{CD} 3 \zeta$ contributes to the plasticity of glutamatergic synapses. We found that $\mathrm{CD} 3 \zeta$ promotes GluN2A synaptic localization and the GluN2ACaMKII interaction. CaMKII binding to the NMDAR subunit GluN2 seems to have a key role in the CaMKII-dependent LTP induction (Barria and Malinow, 2005; Zhou et al., 2007). Accordingly, our data show that $\mathrm{CD} 3 \zeta$ is required for activity-induced CaMKII autophosphorylation and GluA1 synaptic recruitment, two key events for LTP and memory formation (Lisman et al., 2012). Together, these data suggest that the role of CD3 $\zeta$ in $\operatorname{cog}$ nition is mediated by its contribution to the NMDAR downstream signaling pathway leading to CaMKII activation and subsequent synaptic translocation of GluA1 (Fig. 8).

Our results showed that the lack of $\mathrm{CD} 3 \zeta$ in cortical neuron cultures inhibited Gly-LTP, as reflected by a marked decrease of CaMKII autophosphorylation and GluAl synaptic translocation. However, electrophysiological recording in $\mathrm{CD} 3 \zeta^{-/-}$hippocampal slices reported an enhanced NMDA-dependent LTP compared with wild-type mice (Huh et al., 2000). The conflicting conclusions between the two studies likely result from the difference in experimental systems (brain hippocampal slices vs cortical neuron culture) and, more importantly, in the paradigm used to induce LTP. Accordingly, LTP elicited by weak tetanic stimu-
$\operatorname{CD} 3 \zeta-1$

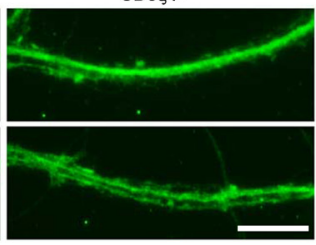

$\frac{\mathrm{CD} 3 \zeta-/-}{\text { CTRL Gly-LTP }}$

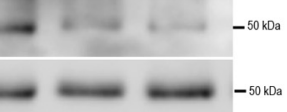

B

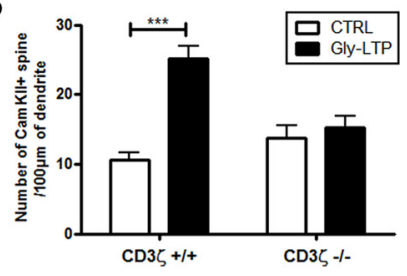

D

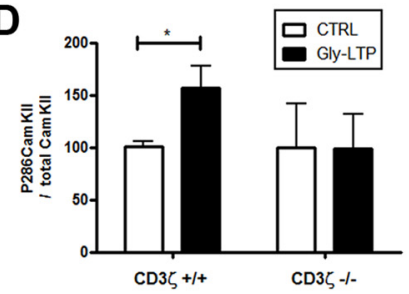

F

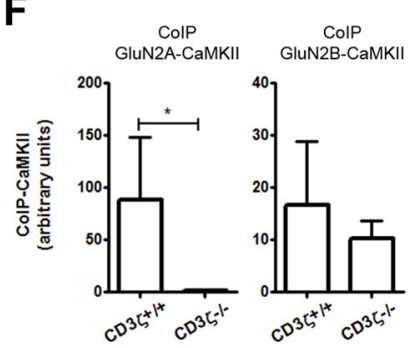

Figure 6. CD3 $\zeta$ is required for the activity-induced CaMKII translocation to dendritic spines, autophosphorylation, and association with the NMDAR subunit GluN2. $\boldsymbol{A}$, CaMKII detected by immunofluorescence showed an increased localization to dendritic 作 \% Triton X-100 were immunoprecipitated with GluN2A or GluN2B antibodies. The immunoprecipitates were ormalized to signal intensity of CaMKII input, divided by signal intensity of IP GluN2A or GluN2B. Values are mean \pm SEM $(n=$ $4-6)$. ${ }^{*} p<0.05$, Mann-Whitney test.

lations of 5 or $10 \mathrm{~Hz}$ was abrogated in LIM kinase (LIMK1)deficient mice, whereas a more robust stimulation induced by high frequency of 50 or $100 \mathrm{~Hz}$ was shown to have the opposite effect in LIMK1 knock-out mice, which then exhibited enhanced LTP (Meng et al., 2002). We induced NMDAR-dependent LTP in cortical neurons by a Gly-induced protocol that requires spontaneous release of glutamate from opposing terminals to specifically activate postsynaptic NMDARs, which is thought to mimic standard weak LTP protocol (Lu et al., 2001; Kopec et al., 2006; Fortin et al., 2010). In contrast, Huh et al. used a strong, highfrequency stimulation $(4 \times 100 \mathrm{~Hz})$ to induce LTP (Huh et al., 2000). Similarly to LIMK1, the lack of CD3 $\zeta$ might differentially affect the propensity to develop LTP depending on the paradigm used to induce LTP.

The lack of $\mathrm{CD} 3 \zeta$ in GluN2A-containing protein complex affects GluN2A in two ways: (1) its synaptic localization, as demonstrated in vivo by immunoblot of synaptosome-enriched fraction from $\mathrm{CD} 3 \zeta^{-1-}$ mice brain and in vitro by GluN2A immunofluorescence of cortical neuron cultures, and (2) its association with PSD95 as demonstrated by co-IP experiments. Given 

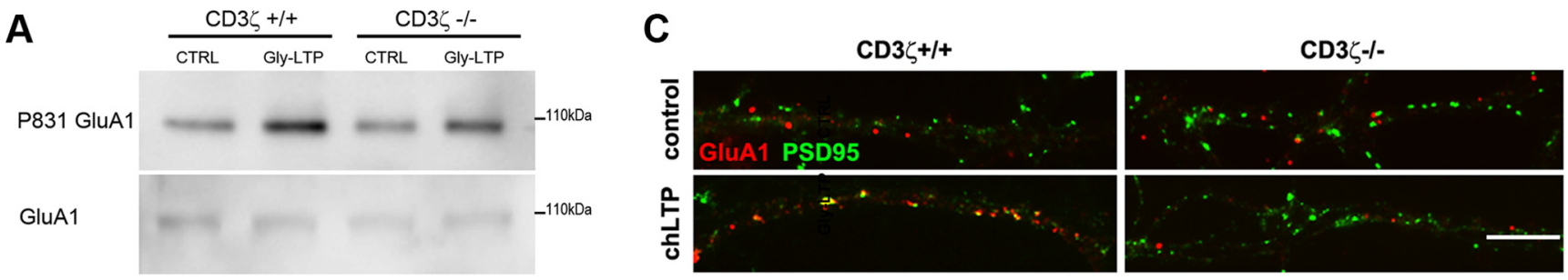

B

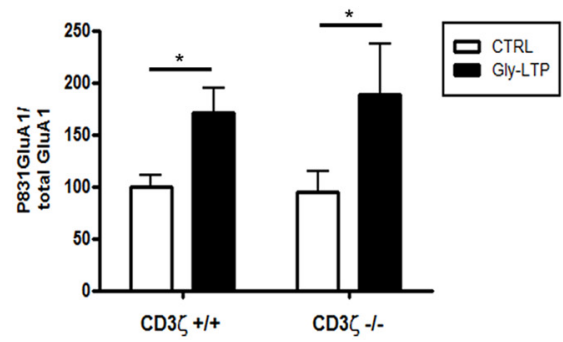

D

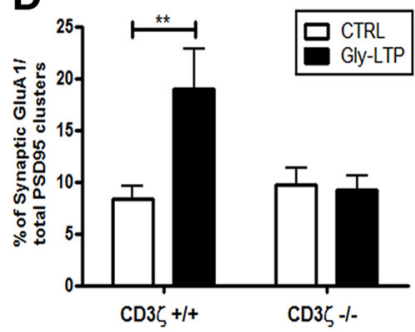

E

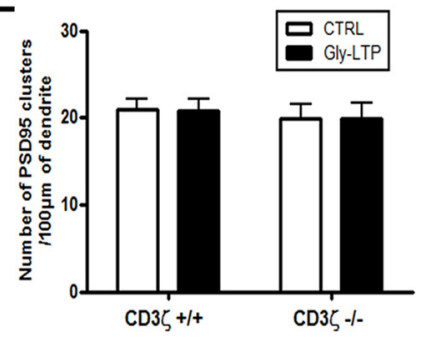

Figure 7. $C D 3 \zeta$ is required for activity-induced GluA1 synaptic translocation. $A$, Western blot analysis of the activity-induced increase of GluA1 phosphorylation at 5831 in $C D 3 \zeta \zeta^{+/+}$and CD3 $\zeta^{-1-}$ cultured cortical neurons. Cultured neurons at 15 DIV were stimulated by Gly-LTP and the cellular extracts were analyzed by Western blot using antibodies against phospho-S831 GluA1 and total GluA1. B, Quantification is shown as a ratio of phospho-S831 GluA1 to total GluA1 normalized to the mean control. Gly-LTP induced a similar increase of phospho-S831 in CD3 $\zeta^{+/+}$and $\mathrm{CD} 3 \zeta^{-1-}$ neurons compared with unstimulated cells. Values are mean $\pm \operatorname{SEM}(n=4) .{ }^{*} p<0.05$, two-way ANOVA. C, GluA1 detected by immunofluorescence (red) showed an increased synaptic localization in response to Gly-LTP in $C D 3 \zeta^{+/+}$, but not $\mathrm{CD} 3 \zeta^{-/-}$, cultured cortical neurons. Scale bar, $5 \mu \mathrm{m}$. D, Levels of synaptic GluA1 determined by the number of GluA1-PSD95 clusters/total GluA1 clusters. Data are mean \pm SEM $(n=4) .{ }^{* *} p<0.01$, two-way ANOVA with Bonferroni post hoc test. $\boldsymbol{E}$, The number of PSD95 clusters per length of dendrite was determined in 15 DIV $\mathrm{CD} 3 \zeta^{+/+}$and $\operatorname{CD} 3 \zeta^{-/-}$cultured cortical neurons immunostained for PDS95. Data are mean \pm SEM $(n=4)$.

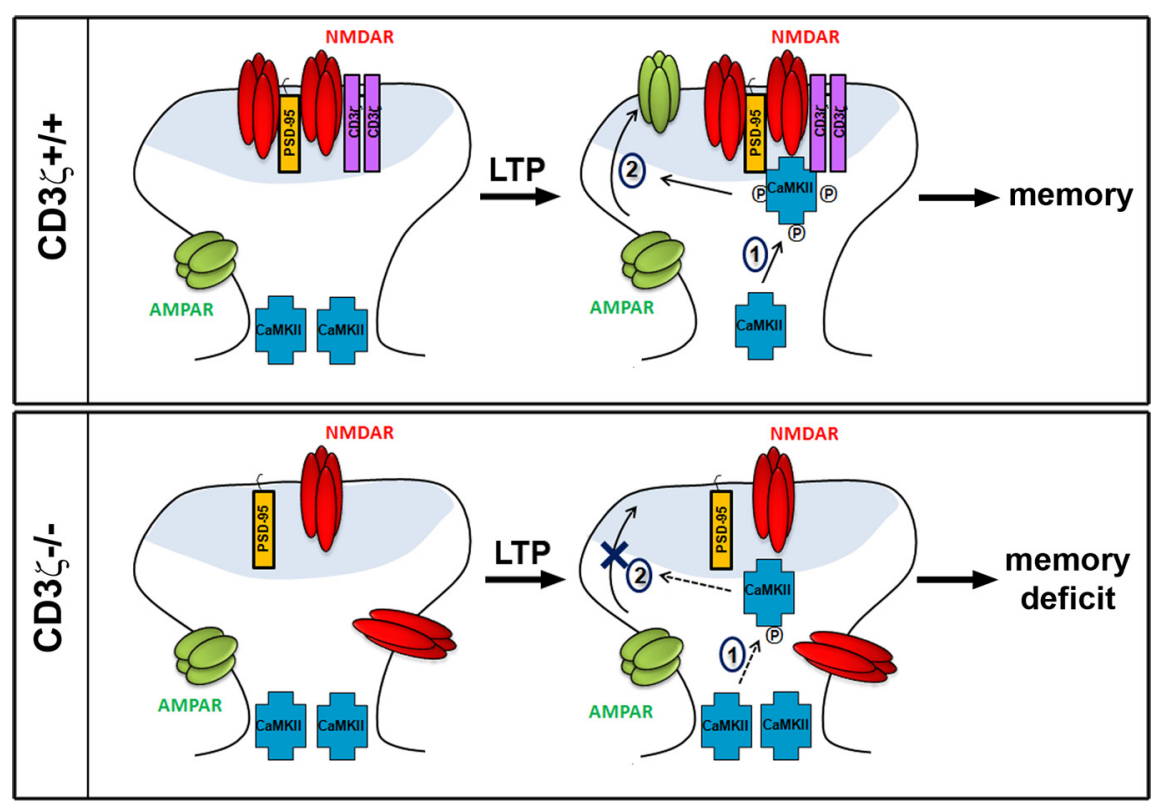

Figure 8. Schematic representation of altered plasticity and mechanisms underlying this effect in $\mathrm{CD} 3 \zeta^{-1-}$ mice. In the absence of CD3 $\zeta$, the NMDAR-PSD95 complex is loose, thereby inducing a decrease of the synaptic localization of NMDARs, which in turn affects NMDA-dependent CaMKII synaptic translocation and activation (1). The defects of CaMKII activation restrain AMPARs synaptic recruitment during LTP (2).

the key involvement of PSD95 in the expression and stabilization of GluN2A at synapses (Kornau et al., 1995; Sprengel et al., 1998; Steigerwald et al., 2000), the role of $\mathrm{CD} 3 \zeta$ in regulating synaptic GluN2A might be mediated through its regulation of the GluN2A-PSD95 interaction. However, an $\sim 50 \%$ reduction of synaptic GluN2A was observed in $\mathrm{CD} 3 \zeta^{-1-}$ mice, in contrast to the total loss of the GluN2A-PSD95 association in $\mathrm{CD} 3 \zeta^{-1-}$ mice brains. This discordance suggests that the synaptic localization of GluN2A also relies on mechanisms independent of a GluN2A-PSD95 interaction, consistent with previous studies show- ing significant functional role of other MAGUKs, such as SAP97 and SAP102, and additional GluN2-binding partners, such as $\alpha$-actinin, in the synaptic localization of NMDARs (Wyszynski et al., 1997; Dunah et al., 2000). Our data showed that the decrease in synaptic GluN2A in $\mathrm{CD} 3 \zeta^{-1-}$ neurons is associated with a massive reduction of Gly-LTP-induced translocation of CaMKII to dendritic spine and CaMKII autophosphorylation at T286. It is now well established that CaMKII autophosphorylation is a significant downstream event of NMDARs activation, leading to the increase of AMPAR-mediated transmission during plasticity, and we show now that $\mathrm{CD} 3 \zeta$ is required in this process. The maintenance of CaMKII at postsynaptic sites for prolonged period of time and persistence into an active state critically depends on CaMKII binding to the GluN2 subunit of NMDARs (Lisman et al., 2012). Accordingly, we found a defect in CaMKII interaction with GluN2 in $\mathrm{CD} 3 \zeta^{-1-}$ mice brain as reflected by lower co-IP of CaMKII with GluN2A in $\mathrm{CD} 3 \zeta^{-1-}$ mice. $\mathrm{CD} 3 \zeta$ has three immunoreceptor tyrosine-based activation motifs (ITAMs) in its intracellular domain that serve as a docking site for several kinases, enabling the formation of TCR-signaling protein complex during T-cell activation (Pitcher and van Oers, 2003). In analogy with $\mathrm{T}$ cells, neuronal $\mathrm{CD} 3 \zeta$ might contribute to the stabilization of CaMKII in the close proximity of NMDARs at synaptic sites through an ITAM-mediated docking activity.

To address the consequences of $\mathrm{CD} 3 \zeta$-mediated signaling cascade in CaMKII-dependent synaptic plasticity, we focused our studies on two main CaMKII-dependent signaling processes 
leading to the potentiation of AMPA receptor function. One process is the phosphorylation at $\mathrm{S} 831$ of the GluA1 subunit of the AMPAR resulting in an increase of the channel conductance (Derkach et al., 1999; Patterson et al., 2010; Lisman et al., 2012). The second process involves an increase in the number of AMPARs at synapses (Shi et al., 1999). Extrasynaptic mobile AMPARs are trapped through the CaMKII-mediated phosphorylation of the auxiliary subunit stargazin and its binding to PDZ domain scaffolds, such as PSD95 (Tomita et al., 2005; Bats et al., 2007; Opazo et al., 2010). We found that the lack of $\mathrm{CD} 3 \zeta$ had no effect on the phosphorylation of GluA1 at S831, but inhibited the activity-induced synaptic recruitment of GluA1. This finding is consistent with previous studies demonstrating that the capture of AMPARs at synapse through CaMKII-mediated signaling is independent of AMPAR phosphorylation at S831 (Opazo et al., 2010). Therefore, $\mathrm{CD} 3 \zeta$ is required for the activity-driven enhancement of AMPARs at synapses. The exact mechanism by which $\mathrm{CD} 3 \zeta$ selectively supports the synaptic recruitment of GluA1 remains to be determined. The cytoplasmic domain of $\mathrm{CD} 3 \zeta$ contains a stretch of basic amino acid residues shown to bind with high affinity to phosphoinositides, including phosphatidylinositol-(3,4,5)-trisphosphate (PIP3). This CD3 - $^{-}$ phosphoinositide interaction is required in $\mathrm{T}$ cells for the stable accumulation of the TCR-CD3 complex at the immunological synapse (DeFord-Watts et al., 2011). PIP3 plays a critical role in the maintenance and in the CaMKII-induced increase of AMPARs at synaptic membranes (Arendt et al., 2010). PIP3 seems to act at a very local scale by ensuring PSD-95-mediated clustering of AMPARs at the postsynaptic membrane and, therefore, preventing receptor dispersion into the neighboring extrasynaptic membrane of the spine. It is possible that $\mathrm{CD} 3 \zeta$ contributes to the activity-induced synaptic recruitment of AMPARs by linking PIP3 with AMPAR-stargazin complex through PSD95.

\section{References}

Angibaud J, Louveau A, Baudouin SJ, Nerrière-Daguin V, Evain S, Bonnamain V, Hulin P, Csaba Z, Dournaud P, Thinard R, Naveilhan P, Noraz N, Pellier-Monnin V, Boudin H (2011) The immune molecule CD3zeta and its downstream effectors ZAP-70/Syk mediate ephrin signaling in neurons to regulate early neuritogenesis. J Neurochem 119:708-722. CrossRef Medline

Arendt KL, Royo M, Fernández-Monreal M, Knafo S, Petrok CN, Martens JR, Esteban JA (2010) PIP3 controls synaptic function by maintaining AMPA receptor clustering at the postsynaptic membrane. Nat Neurosci 13:36-44. CrossRef Medline

Bach ME, Hawkins RD, Osman M, Kandel ER, Mayford M (1995) Impairment of spatial but not contextual memory in CaMKII mutant mice with a selective loss of hippocampal LTP in the range of the theta frequency. Cell 81:905-915. CrossRef Medline

Barco A, Patterson SL, Patterson S, Alarcon JM, Gromova P, Mata-Roig M, Morozov A, Kandel ER (2005) Gene expression profiling of facilitated L-LTP in VP16-CREB mice reveals that BDNF is critical for the maintenance of LTP and its synaptic capture. Neuron 48:123-137. CrossRef Medline

Barnes CA (1979) Memory deficits associated with senescence: a neurophysiological and behavioral study in the rat. J Comp Physiol Psychol 93:74-104. CrossRef Medline

Barria A, Malinow R (2005) NMDA receptor subunit composition controls synaptic plasticity by regulating binding to CaMKII. Neuron 48:289-301. CrossRef Medline

Bats C, Groc L, Choquet D (2007) The interaction between Stargazin and PSD-95 regulates AMPA receptor surface trafficking. Neuron 53:719734. CrossRef Medline

Baudouin SJ, Angibaud J, Loussouarn G, Bonnamain V, Matsuura A, Kinebuchi M, Naveilhan P, Boudin H (2008) The signaling adaptor protein
CD3zeta is a negative regulator of dendrite development in young neurons. Mol Biol Cell 19:2444-2456. CrossRef Medline

Boulanger LM (2009) Immune proteins in brain development and synaptic plasticity. Neuron 64:93-109. CrossRef Medline

Brynskikh A, Warren T, Zhu J, Kipnis J (2008) Adaptive immunity affects learning behavior in mice. Brain Behav Immun 22:861-869. CrossRef Medline

DeFord-Watts LM, Dougall DS, Belkaya S, Johnson BA, Eitson JL, Roybal KT, Barylko B, Albanesi JP, Wülfing C, van Oers NS (2011) The CD3 zeta subunit contains a phosphoinositide-binding motif that is required for the stable accumulation of TCR-CD3 complex at the immunological synapse. J Immunol 186:6839-6847. CrossRef Medline

Derecki NC, Cardani AN, Yang CH, Quinnies KM, Crihfield A, Lynch KR, Kipnis J (2010) Regulation of learning and memory by meningeal immunity: a key role for IL-4. J Exp Med 207:1067-1080. CrossRef Medline Derkach V, Barria A, Soderling TR (1999) $\mathrm{Ca}^{2+} /$ calmodulin-kinase II enhances channel conductance of alpha-amino-3-hydroxy-5-methyl-4isoxazolepropionate type glutamate receptors. Proc Natl Acad Sci U S A 96:3269-3274. CrossRef Medline

Dunah AW, Wyszynski M, Martin DM, Sheng M, Standaert DG (2000) alpha-actinin-2 in rat striatum: localization and interaction with NMDA glutamate receptor subunits. Brain Res Mol Brain Res 79:77-87. Medline

Fehr T, Lucas CL, Kurtz J, Onoe T, Zhao G, Hogan T, Vallot C, Rao A, Sykes M (2010) CD8 T cell-intrinsic role for the calcineurin-NFAT pathway for tolerance induction in vivo. Blood 115:1280-1287. CrossRef Medline

Fortin DA, Davare MA, Srivastava T, Brady JD, Nygaard S, Derkach VA, Soderling TR (2010) Long-term potentiation-dependent spine enlargement requires synaptic $\mathrm{Ca}^{2+}$-permeable AMPA receptors recruited by CaM-kinase I. J Neurosci 30:11565-11575. CrossRef Medline

Fourgeaud L, Davenport CM, Tyler CM, Cheng TT, Spencer MB, Boulanger LM (2010) MHC class I modulates NMDA receptor function and AMPA receptor trafficking. Proc Natl Acad Sci U S A 107:22278-22283. CrossRef Medline

Giese KP, Fedorov NB, Filipkowski RK, Silva AJ (1998) Autophosphorylation at Thr286 of the alpha calcium-calmodulin kinase II in LTP and learning. Science 279:870-873. CrossRef Medline

Glynn MW, Elmer BM, Garay PA, Liu XB, Needleman LA, El-Sabeawy F, McAllister AK (2011) MHCI negatively regulates synapse density during the establishment of cortical connections. Nat Neurosci 14:442-451. CrossRef Medline

Goddard CA, Butts DA, Shatz CJ (2007) Regulation of CNS synapses by neuronal MHC class I. Proc Natl Acad Sci U S A 104:6828-6833. CrossRef Medline

Grunwald IC, Korte M, Adelmann G, Plueck A, Kullander K, Adams RH, Frotscher M, Bonhoeffer T, Klein R (2004) Hippocampal plasticity requires postsynaptic ephrinBs. Nat Neurosci 7:33-40. CrossRef Medline

Hudmon A, Schulman H (2002) Structure-function of the multifunctional $\mathrm{Ca}^{2+} /$ calmodulin-dependent protein kinase II. Biochem J 364:593-611. CrossRef Medline

Huh GS, Boulanger LM, Du H, Riquelme PA, Brotz TM, Shatz CJ (2000) Functional requirement for class I MHC in CNS development and plasticity. Science 290:2155-2159. CrossRef Medline

Inoue E, Deguchi-Tawarada M, Togawa A, Matsui C, Arita K, KatahiraTayama S, Sato T, Yamauchi E, Oda Y, Takai Y (2009) Synaptic activity prompts gamma-secretase-mediated cleavage of EphA4 and dendritic spine formation. J Cell Biol 185:551-564. CrossRef Medline

Kipnis J, Cohen H, Cardon M, Ziv Y, Schwartz M (2004) T cell deficiency leads to cognitive dysfunction: implications for therapeutic vaccination for schizophrenia and other psychiatric conditions. Proc Natl Acad Sci U S A 101:8180-8185. CrossRef Medline

Kipnis J, Gadani S, Derecki NC (2012) Pro-cognitive properties of T cells. Nat Rev Immunol 12:663-669. CrossRef Medline

Kopec CD, Li B, Wei W, Boehm J, Malinow R (2006) Glutamate receptor exocytosis and spine enlargement during chemically induced long-term potentiation. J Neurosci 26:2000-2009. CrossRef Medline

Kornau HC, Schenker LT, Kennedy MB, Seeburg PH (1995) Domain interaction between NMDA receptor subunits and the postsynaptic density protein PSD-95. Science 269:1737-1740. CrossRef Medline

Kristensen AS, Jenkins MA, Banke TG, Schousboe A, Makino Y, Johnson RC, Huganir R, Traynelis SF (2011) Mechanism of $\mathrm{Ca}^{2+} /$ calmodulindependent kinase II regulation of AMPA receptor gating. Nat Neurosci 14:727-735. CrossRef Medline 
Lavezzari G, McCallum J, Lee R, Roche KW (2003) Differential binding of the AP-2 adaptor complex and PSD-95 to the C-terminus of the NMDA receptor subunit NR2B regulates surface expression. Neuropharmacology 45:729-737. CrossRef Medline

Liao D, Scannevin RH, Huganir R (2001) Activation of silent synapses by rapid activity-dependent synaptic recruitment of AMPA receptors. J Neurosci 21:6008-6017. Medline

Lisman J, Yasuda R, Raghavachari S (2012) Mechanisms of CaMKII action in long-term potentiation. Nat Rev Neurosci 13:169-182. CrossRef Medline

Liu CP, Ueda R, She J, Sancho J, Wang B, Weddell G, Loring J, Kurahara C, Dudley EC, Hayday A (1993) Abnormal T cell development in CD3zeta $^{-1-}$ mutant mice and identification of a novel $\mathrm{T}$ cell population in the intestine. EMBO J 12:4863-4875. Medline

Love PE, Shores EW, Johnson MD, Tremblay ML, Lee EJ, Grinberg A, Huang SP, Singer A, Westphal H (1993) T cell development in mice that lack the zeta chain of the T cell antigen receptor complex. Science 261:918921. CrossRef Medline

Lu W, Man H, Ju W, Trimble WS, MacDonald JF, Wang YT (2001) Activation of synaptic NMDA receptors induces membrane insertion of new AMPA receptors and LTP in cultured hippocampal neurons. Neuron 29:243-254. CrossRef Medline

Malissen M, Gillet A, Rocha B, Trucy J, Vivier E, Boyer C, Köntgen F, Brun N, Mazza G, Spanopoulou E, et al. (1993) T cell development in mice lacking the CD3-zeta/eta gene. ЕMBO J 12:4347-4355. Medline

Meng Y, Zhang Y, Tregoubov V, Janus C, Cruz L, Jackson M, Lu WY, MacDonald JF, Wang JY, Falls DL, Jia Z (2002) Abnormal spine morphology and enhanced LTP in LIMK-1 knockout mice. Neuron 35:121-133. CrossRef Medline

Murai KK, Pasquale EB (2004) Eph receptors, ephrins, and synaptic function. Neuroscientist 10:304-314. CrossRef Medline

Nakamura K, Hirai H, Torashima T, Miyazaki T, Tsurui H, Xiu Y, Ohtsuji M, Lin QS, Tsukamoto K, Nishimura H, Ono M, Watanabe M, Hirose S (2007) CD3 and immunoglobulin G Fc receptor regulate cerebellar functions. Mol Cell Biol 27:5128-5134. CrossRef Medline

Oh MC, Derkach VA (2005) Dominant role of the GluR2 subunit in regulation of AMPA receptors by CaMKII. Nat Neurosci 8:853-854. CrossRef Medline

Ohno H, Aoe T, Taki S, Kitamura D, Ishida Y, Rajewsky K, Saito T (1993) Developmental and functional impairment of $\mathrm{T}$ cells in mice lacking CD3 zeta chains. EMBO J 12:4357-4366. Medline

Opazo P, Labrecque S, Tigaret CM, Frouin A, Wiseman PW, De Koninck P, Choquet D (2010) CaMKII triggers the diffusional trapping of surface AMPARs through phosphorylation of stargazin. Neuron 67:239-252. CrossRef Medline

Patterson MA, Szatmari EM, Yasuda R (2010) AMPA receptors are exocytosed in stimulated spines and adjacent dendrites in a Ras-ERKdependent manner during long-term potentiation. Proc Natl Acad Sci U S A 107:15951-15956. CrossRef Medline

Pitcher LA, van Oers NS (2003) T-cell receptor signal transmission: who gives an ITAM? Trends Immunol 24:554-560. CrossRef Medline
Ron-Harel N, Segev Y, Lewitus GM, Cardon M, Ziv Y, Netanely D, JacobHirsch J, Amariglio N, Rechavi G, Domany E, Schwartz M (2008) Agedependent spatial memory loss can be partially restored by immune activation. Rejuvenation Res 11:903-913. CrossRef Medline

Samelson LE, Harford JB, Klausner RD (1985) Identification of the components of the murine $\mathrm{T}$ cell antigen receptor complex. Cell 43:223-231. CrossRef Medline

Sanz-Clemente A, Nicoll RA, Roche KW (2013) Diversity in NMDA receptor composition: many regulators, many consequences. Neuroscientist 19:62-75. CrossRef Medline

Sharma K, Fong DK, Craig AM (2006) Postsynaptic protein mobility in dendritic spines: long-term regulation by synaptic NMDA receptor activation. Mol Cell Neurosci 31:702-712. CrossRef Medline

Sheng M, Kim E (2011) The postsynaptic organization of synapses. Cold Spring Harb Perspect Biol 3

Shi SH, Hayashi Y, Petralia RS, Zaman SH, Wenthold RJ, Svoboda K, Malinow R (1999) Rapid spine delivery and redistribution of AMPA receptors after synaptic NMDA receptor activation. Science 284:1811-1816. CrossRef Medline

Sprengel R, Suchanek B, Amico C, Brusa R, Burnashev N, Rozov A, Hvalby O, Jensen V, Paulsen O, Andersen P, Kim JJ, Thompson RF, Sun W, Webster LC, Grant SG, Eilers J, Konnerth A, Li J, McNamara JO, Seeburg PH (1998) Importance of the intracellular domain of NR2 subunits for NMDA receptor function in vivo. Cell 92:279-289. CrossRef Medline

Steigerwald F, Schulz TW, Schenker LT, Kennedy MB, Seeburg PH, Köhr G (2000) C-Terminal truncation of NR2A subunits impairs synaptic but not extrasynaptic localization of NMDA receptors. J Neurosci 20:45734581. Medline

Tomita S, Adesnik H, Sekiguchi M, Zhang W, Wada K, Howe JR, Nicoll RA, Bredt DS (2005) Stargazin modulates AMPA receptor gating and trafficking by distinct domains. Nature 435:1052-1058. CrossRef Medline

Wolf SA, Steiner B, Akpinarli A, Kammertoens T, Nassenstein C, Braun A, Blankenstein T, Kempermann G (2009) CD4-positive T lymphocytes provide a neuroimmunological link in the control of adult hippocampal neurogenesis. J Immunol 182:3979-3984. CrossRef Medline

Wyszynski M, Lin J, Rao A, Nigh E, Beggs AH, Craig AM, Sheng M (1997) Competitive binding of alpha-actinin and calmodulin to the NMDA receptor. Nature 385:439-442. CrossRef Medline

Xu HP, Chen H, Ding Q, Xie ZH, Chen L, Diao L, Wang P, Gan L, Crair MC, Tian N (2010) The immune protein CD3zeta is required for normal development of neural circuits in the retina. Neuron 65:503-515. CrossRef Medline

Yirmiya R, Goshen I (2011) Immune modulation of learning, memory, neural plasticity and neurogenesis. Brain Behav Immun 25:181-213. CrossRef Medline

Zhou Y, Takahashi E, Li W, Halt A, Wiltgen B, Ehninger D, Li GD, Hell JW, Kennedy MB, Silva AJ (2007) Interactions between the NR2B receptor and CaMKII modulate synaptic plasticity and spatial learning. J Neurosci 27:13843-13853. CrossRef Medline 